Çinpolat, E. (2018). Türkçe ders kitaplarında yer alan öykülerdeki kişilerin karakter özellikleri üzerine bir inceleme. Ana Dili Eğitimi Dergisi, 6(4), 1016-1040.

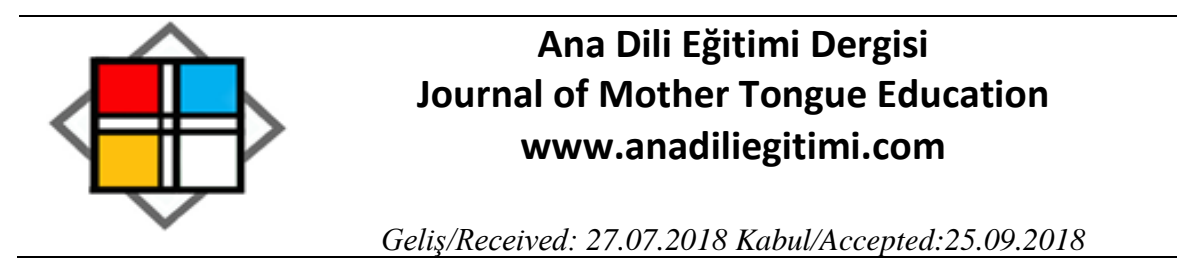

\title{
Türkçe Ders Kitaplarında Yer Alan Öykülerdeki Kişilerin Karakter Özellikleri Üzerine Bir inceleme*
}

Öz

\author{
Enes ÇINPOLAT**
}

Ders kitapları, öğrenme etkinliğindeki temel yapısıyla öğrencilerin gelişim sürecinde önemli bir değişkendir. Türkçe ders kitapları işlevsel bir ortam hazırlayıcı olarak eğitsel sürecin şekillenmesinde başat rol oynar. Gelişim çağında olan ilkokul ve ortaokul öğrencileri, Türkçe ders kitaplarında bulunan öykülerdeki kahramanlar ile özdeşim kurmaya yönelirler. Dolayısıyla Türkçe ders kitaplarında yer alan öykülerdeki kişilerin taşıdığı karakter özellikleri belirleyici önemdedir. Bu çalışma, Millî Eğitim Bakanlığı tarafından yayınlanan 1, 3, 5, 6, 8. sınıf Türkçe ders kitapları ile Dikey Yayıncılık tarafından hazırlanan 2, Doku Yayıncılık tarafından hazırlanan 4, Ez-De Yayıncılık tarafından hazırlanan 7. sınıf Türkçe ders kitaplarındaki öykülerde bulunan kişilerin Sever (2007) tarafından belirlenen karakter özelliklerine göre incelenmesini içermektedir. Bu araştırma, nitel araştırma geleneğine dayalı bir doküman analizi çalışmasıdır. Verilerin çözümlenmesinde betimsel analiz yaklaşımı benimsenmiştir. Araştırma sonucunda ilkokul ve ortaokul Türkçe ders kitaplarında bulunan tüm öykülerdeki (52) karakterlere bakıldığında incelenen 260 karakter açıklık ve kapalılık yönünden $\% 13,46$ 'sı açık, devingenlik ve durağanlık yönünden ise \%11,53'ü devingen karakter özellikleri gösterdiği tespit edilmiştir. İncelenen 52 öykünün 24'ünde açık karakter özellikleri taşıyan kişiye, $28^{\prime}$ inde ise devingen karakter özellikleri taşıyan kişiye yer verilmediği görülmektedir. Bu durum çocuklar için olumsuz sonuçlar oluşturabilecek bir nitelik taşımaktadır. Çalışmada ulaşılan sonuçlara dayalı olarak bir dizi öneri getirilmiştir.

Anahtar Kelimeler: ilkokul, ortaokul, Türkçe ders kitapları, öykü, karakter özellikleri

\section{An Investigation of the Character Traits of People in the Stories in Turkish Textbooks}

\begin{abstract}
Textbooks constitute an important element in the development process of students because of their fundamental role in learning. Turkish textbooks play a major role in shaping the educational process as an agent that establishes such a functional environment. Elementary school students who are going through the process of growing up tend to identify themselves with the heroes in the stories in Turkish textbooks. Therefore, the character traits of people in the stories in Turkish textbooks are important. This study presents an analysis of the character traits of people in the stories in grades 1, 3, 5, 6, and 8 Turkish textbooks by the Ministry of Education, grade 2 textbook by Dikey Publishing, grade 4 textbook by Doku Publishing and grade 7 textbook by Ez-De Publishing, using the criteria set forth by Sever (2007). The research uses document analysis which is in the qualitative research tradition. Descriptive analysis approach was used to analyze the data. The analysis revealed that in the 52 stories in the above mentioned elementary and secondary school Turkish textbooks, $13,46 \%$ of the 260 characters that were analyzed were identified as open in terms of openness and closedness, $11,53 \%$ were dynamic in terms of dynamicality and stability. In the stories, open characters were not included in 24 stories and
\end{abstract}

\footnotetext{
* Bu çalışma III. Ines International Education And Social Science Congress'de (28 Nisan-1 Mayıs 2018, Antalya) sözlü bildiri olarak sunulmuştur

** Arş. Gör., Ordu Üniversitesi, Eğitim Fakültesi, Türkçe Eğitimi Bölümü, Ordu, enescinpolat@odu.edu.tr
} 
dynamic characters were not included in 28 stories. This may create negative consequences for children. A set of recommendations were given based on the results of the study.

Keywords: elementary school, secondary school, Turkish textbooks, story, character traits

\section{Giriş}

Her yazınsal ürün belirli ögelerden oluşan bir dizgedir. Bu yapı olay, kişi, zaman ve uzam değişkenlerini kapsar. Kurgusal anlatının yapı taşlarını devinimsel biçimde birbiriyle karşılıklı olarak ilişki kurmasını sağlayan ana yönlendirici ise kişidir. Kişi, kurgusal bir anlatının belirleyici ve temel ögelerindendir. Kişi yazınsal yapıtta ilginin merkezindedir, çünkü diğer ögeler onun için vardırlar ve söz konusu dünya onunla bir anlam ve işlev kazanmaktadır (Tekin, 2001).

Karakter, "bir edebi eserde kendine has duygu, düşünce ve davranışlarıyla tanıtılan veya canlandırılan kişilik" (Ayverdi, 2011: 626) anlamına gelir. Bir başka anlatımla aksiyonla gelişen, ama bu aksiyona yön veren bir ögedir (Nutku, 2001). Kurgusal metinde okur da karakterler aracilı̆ı̆yla, onlara karşı ya da onların yanında veya dışında bir taraf belirleyerek metnin dünyasına katıı (Karataş, 2014).

Yazınsal nitelikli çocuk edebiyatı metinlerindeki karakterler çocuk okur için önemlidir. Çocuklar, kitaptaki kahramanlarla iletişim ve özdeşlik kurarak yapıtın dünyasına dâhil olurlar. Bu amaçlara ulaşılabilmek için kahramanların iyi çizilmesi gerekmektedir. Fakat bunlar karakterlerin aşırı idealize edilmesi demek değildir (Şimşek, 2005). Karakterlerin aşırı idealize edilmesiyle didaktik ve yapay karakterler oluşmuştur. Daha insani özellikler gösteren karakterler ile çocuğun özdeşim kurması daha kolaydır. Çünkü çocuk da eserde anlatılanlar gibi gerçek hayatta çelişkiler yaşamakta, hatalar yapmakta ve bunların sonucunda kişilik gelişimine yön vermektedir (Karataş, 2014). Ayrıca, çocuklar kimi zaman kişiliklerine eş yönde kimi zaman zıt yönde, kimi zaman farkı kimi zaman ise benzer beklenti ve yönelimlere sahip karakterlerle karşı karşıya gelirler. Daha kuşatıcı bir anlatımla, yazınsal niteliğe sahip çocuk kitapları içerisinde bulundurduğu olumlu ya da olumsuz karakterler ile çocukların kendilerini ve diğer insanları tanımasına, farklııkları görebilmesine, iyiyi tanıyıp istemeleri ve iyi eylemlerde bulunmalarına yardımcı olabilir (Aslan, 2007; Karatay, 2011).

Nitelikli bir edebiyat yapıtı zihni olduğu kadar kalbi de eğiterek merhameti geliştirebilir. Bu, çocukların yeni, daha önce sahip olmadığı fikirler geliştirmesine yardımcı olabilir. [Karakterlere öykünen] çocukların düş gücünü genişletebilir, yeni deneyimler yaratarak, eskilerini zenginleştirebilir. Gerçek, adil ve güzel olana ilişkin bir anlam odağı oluşturabilir (Huck, 1982).

Yazınsal ürünlerde bulunan karakterleri Sever (2007), açık ve kapalı, devingen ve durağan biçiminde sınıflandırır. Açık yahut iyi geliştirilmiş olarak adlandırılan karakterler, okur tarafından iyi tanınmakta ve olaylar içerisinde çeşitli özellikleri okurun belleğine yer etmektedir. Bu karakterlerin duygu ve düşünceleri, neler yapabilecekleri ve başkalarının onlara ilişkin yargıları bilinir. Kapalı 
Türkçe Ders Kitaplarında Yer Alan Öykülerdeki Kişilerin Karakter Özellikleri Üzerine Bir İnceleme

karakterler olay örgüsünde yüzeysel olarak tanıtılır ve okurlar haklarında çok şey bilmezler. Bu tip karakterler okurun ilgisinin kahramana yönlendirilmesinde rol oynayarak arka planda kalırlar. Kapalı karakterlerin kullanımında temel amaç, çocuklara açık karakterin özellikleri ile kapalı karakterin özellikleri arasında bir karşılaştırma yapmasına imkân sağlamaktır. Devingen karakterler hikâyenin içerisinde değişim göstererek yeni kişisel davranışlar elde eden, yeni değerler geliştiren karakterlerdir. Ayrıca hikâye içerisinde yaşanan değişim çocuk okur tarafından inandırıcı olmalıdır. Çocuk bu değişimlere neden olan olayları algılayabilmeli, bu olaylar arasında nedensellik ilişkisi kurabilmelidir. Aksi takdirde çocuk, hikâyeye olan inancını kaybedebilmektedir. Durağan karakterler ise hikâye içerisinde kayda değer kişilik değişimleri yaşamazlar (Sever, 2007).

Çocuk okur olaya dayalı türlere daha çok ilgi duyar. Bu türler arasında öykü kısa oylumu, kurgusal gerçekçiliği, olay ve karakterleri içine alan devingen yapısıyla (Özdemir, 2007) çocuk okurun dünyasına uygun bir içerik taşır. Kurmaca yazılar arasında öykü türünün ders kitaplarında en çok yer verilen yazınsal tür olduğu araştırmacıların ortak görüşüdür (Baş, 2003; Kolaç, 2009; Solak ve Yaylı, 2009). Buna göre ders kitaplarında yer alan öykülerin yaş grupları, yönelim, bilişsel ve duyuşsal gelişim düzeyleri, karakter örnekleri dikkate alınarak sunulması önemlidir. Bu nitelikte metinlerin seçilmesi ders kitabı hazırlayıcılarının doğal sorumluluğudur.

Çocuk, kişilik gelişimi sürecinde kendini örnek bir modelle özdeşleştirir. Bu örnekler, başlangıçta ailede ebeveynler iken daha sonra yerini kitaplara ve kurgusal kahramanlara bırakır. Bu bakımdan kurgusal kahramanların sağlıksız olması çocuk okurun bir özdeşim kuramamasına ya da olumsuz bir özdeşim kurmasına yol açabilir. Ders kitaplarındaki öykülerde yer alan karakterler çocuklar için birer öykünme aracı, örnek model olduğu için araştırma ortaya koyacağı sonuçlar bakımından önemli ve gereklidir.

Alanyazındaki araştırmalara bakıldığında Türkçe ders kitaplarına ilişkin bazı çalışmaların bulunduğu (Akyol, 2001; Çalık, 2001; Baş, 2003; Aslan, 2006; Erdoğan, 2007; Açıkgöz, 2008; Göçer, 2008; Karagöz, 2009; Solak ve Yaylı, 2009; Karadağ ve Kurudayığlu, 2010; Esmer, 2011; Güftâ ve Kan, 2011; Küçük, 2011; Küçükbasmacı ve Öztürk, 2011; Nayır ve Kepenekçi, 2011; Özalp, 2011; Tolğay, 2011; Aydın, 2012; Karatay ve Pektaş, 2012; Öz, 2012; Aydın ve Yangil, 2013; Ceran ve Bozarslan, 2013; Gür, Coşkun ve Sağlam, 2013; Kıymaz ve Koç, 2013; Okur ve Arı, 2013; Ercan, 2014; Susar Kırmızı, 2014; Temizkan, 2014; Yaylı ve Kitiş Çınar, 2014; Tüm, 2016; Uzuner Yurt, 2017) görülmektedir. Bunun yanında Türkçe ders kitaplarında çocuk edebiyatının yerinin araştırıldı̆̆ı (Dilidüzgün, 2004; Evren, 2008; Uludoğan, 2008; Işık Demir, 2009; Doğan ve Gülüşen, 2011; Şahbaz ve Çekici, 2012; Bağcı ve Ünal, 2013; Küçükavşar ve Hasırcı, 2013; Okur ve Arı, 2013; Fırat ve Mocan, 2014; Baş ve İnan Yıldız, 2015; Mirzaoğlu ve Akın, 2016) ve Türkçe ders kitaplarındaki öykülerin çalışıldığı araştırmalar da (Demir ve Sinan, 2010; Dilidüzgün, 2010; Çoban ve Tabak, 2011; Mert, 2012; 
Çakır, 2013; Kurudayığlu, Baş ve Aytan, 2013; Temizkan ve Atasoy, 2014; Özkan, 2015) bulunmaktadır. Türkçe ders kitaplarındaki karakterleri irdeleyen çalışma sayısı ise oldukça az ve sınırlıdır. Karagül ve İnce Samur'un (2017) ders kitaplarındaki karakterler odaklı yaptığı çalışma ortaokul Türkçe ders kitaplarındaki karakterlerin tespiti niteliğindedir. Buna karşılık alanyazında bütün Türkçe ders kitaplarında (1-8.sınıf) bulunan öykülerdeki kişilerin karakter özelliklerinin incelenmesine yönelik bir araştırmanın bulunmadığı görülmektedir. Karagül ve Samur (2017) çalışmasının öneriler kısmında "çocukların okuma kültürü edinmelerinde karakter özelliklerinden yararlanılarak çeşitli ve zengin örnekler çerçevesinde özdeşim kurması sağlanmalıdır." şeklinde görüş bildirmektedir. Bu görüş doğrultusunda çalışmanın farklı sınıf düzeylerinde ve okul türlerinde de yapılması gerektiği düşünülmüştür. Dolayısıyla bu çalışma güncel ilkokul ve ortaokul Türkçe ders kitaplarında (1-8.sınıf) yer alan öykülerdeki kişilerin karakter özelliklerini ortaya koymak amacıyla yapılmıştır.

\section{Yöntem}

Bu araştırma nitel araştırma modeline dayalı bir doküman analizi çalışmasıdır. Türkçe ders kitaplarında (1-8.) bulunan öykülerdeki karakterlerin özelliklerini incelemeyi amaçlayan bu çalışmada, çalışma yapılacak kitapların veri sağlamada temel kaynak olması nedeniyle doküman analizi yöntemi benimsenmiştir. Doküman, araştırma öncesi elde mevcut olan herhangi bir şey demektir (Merriam, 2013). Doküman analizi hem basılı hem de web tabanlı bilgi ve belgelerin sistematik bir şekilde ele alınmasını, araştırıması hedeflenen olgu veya olgular hakkında bilgi içeren yazılı materyallerin analizini kapsar (Bowen, 2009; Yıldırım ve Şimşek, 2011). İncelenen dokümanlar, resmi ya da özel olabilir (Creswell, 2013).Yaygın dokümanlar; resmi kayıtlar, mektuplar, gazeteler, şiirler, şarkılar, ortak kayıtlar, hükümet dokümanları, tarihsel dokümanlar, günlükler, otobiyografiler (yaşam öyküsü/özgeçmiş) gibi belgelerdir (Merriam, 2013). Nitel araştırmalarda doküman incelemesi tek başına bir veri toplama yöntemi olarak kullanılabilir. Doküman incelemesi, araştırılması hedeflenen olgu veya olgular hakkında bilgi içeren yazılı materyallerin analizini kapsar (Yıldırım ve Şimşek, 2011).

Verilerin çözümlenmesinde içerik çözümlemesi tekniklerinden biri olan kategorisel çözümleme kullanılmıştır. Kategorisel çözümleme, "belirli bir mesajın önce birimlere bölünmesi ve ardından bu birimlerin önceden saptanmış ölçütlere göre kategoriler halinde gruplandırılmasıdır (Bilgin, 2000: 15; Tavşancıl ve Aslan, 2001). Çalışmanın verileri çözümlenirken, Sever'in (2007) geliştirdiği kategoriler temel alınmıştır. Çözümleme bu sınıflandırmalara göre yapılmış ve bunlara bağıı olarak karakter özelliklerinin sayısal dağılımları ve yüzdelik oranları saptanmıştır. 
Türkçe Ders Kitaplarında Yer Alan Öykülerdeki Kişilerin Karakter Özellikleri Üzerine Bir İnceleme

Çalışmada Türkçe ders kitaplarında (1-8.) yer alan toplam 52 öykü incelenmiştir. Bu öykülerde yer alan toplam 260 karakter Sever (2007) tarafından geliştirilen karakter özellikleri ölçütlerine göre değerlendirilmiştir.

Çalışmada 2017-2018 Eğitim-Öğretim yılında Milli Eğitim Bakanlığı tarafından ilkokul ve ortaokullarda okutulan 1.sınıf, 2.sınıf, 3.sınıf, 4.sınıf, 5.sınıf, 6.sınıf, 7.sınıf, 8.sınıf (toplam sekiz kitap) Türkçe ders kitaplarının tamamı veri kaynağı olarak belirlenmiştir.

Ders kitaplarından ulaşılabilenler doğrudan temin edilmiş, ulaşılamayan kitaplar ise Milli Eğitim Bakanlığı tarafından kurulan Eğitim Bilişim Ağı'ndan (EBA) edinilmiştir. Aşağıda çalışma kapsamında incelenen kitaplarla ilgili bilgiler sunulmuştur.

Tablo 1. Çalışma kapsamında incelenen Türkçe ders kitaplarına ilişkin künye bilgileri

\begin{tabular}{lllll}
\hline Sınıf Düzeyi & Yayınevi & Kabul Yılı & Basım Yılı & Yasal Geçerlilik \\
\hline 1.Sınıf & MEB Yayınları & 2017 & 2017 & $2017-2022$ \\
\hline 2.Sınıf & Dikey Yayıncılık & 2016 & 2017 & $2017-2022$ \\
\hline 3.Sınıf & MEB Yayınları & 2016 & 2017 & $2017-2022$ \\
\hline 4.Sınıf & Doku Yayıncılık & 2012 & 2017 & $2013-2018$ \\
\hline 5.Sınıf & MEB Yayınları & 2017 & 2017 & $2017-2022$ \\
\hline 6.Sınıf & MEB Yayınları & 2017 & 2017 & $2017-2022$ \\
\hline 7.Sınıf & Ez-De Yayıncılık & 2014 & 2017 & $2014-2019$ \\
\hline 8.Sınıf & MEB Yayınları & 2013 & 2017 & $2014-2019$ \\
\hline
\end{tabular}

\section{Bulgular}

Araştırmanın bu bölümünde Türkçe ders kitaplarından elde edilen veriler, tablolaştırılarak bir bütün halinde gösterilmiştir. Karakter özellikleri ile ilgili anlatımlar doğrudan alıntılar yapılarak verilmiştir. Örnek alıntılarda sıklık oranı en fazla ve en düşük olan ifadelere öncelik tanınmıştır.

Tablo 2. 1. Sınıf Türkçe ders kitabına ilişkin bulgular

\begin{tabular}{lcccccccc}
\hline & \multicolumn{2}{c}{ Açık } & \multicolumn{2}{c}{ Kapalı } & \multicolumn{2}{c}{ Devingen } & \multicolumn{2}{c}{ Durağan } \\
\cline { 2 - 10 } Öykü Adları & $f$ & $\%$ & $f$ & $\%$ & $f$ & $\%$ & $f$ & $\%$ \\
\hline Odam Lokanta & - & - & 2 & 10,0 & 1 & 5,0 & 1 & 5,0 \\
\hline Kanat Çırpan Uçurtma & - & - & 2 & 10,0 & - & - & 2 & 10,0 \\
\hline Bir Okul Gezisi & - & - & 6 & 30,0 & - & - & 6 & 30,0 \\
\hline 23 Nisan Kutlu Olsun & - & - & 3 & 15,0 & - & - & 3 & 15,0 \\
\hline Dedemin Madalyası & 1 & 5,0 & 1 & 5,0 & - & - & 2 & 10,0 \\
\hline Ekranza & - & - & 5 & 25,0 & 2 & 10,0 & 3 & 15,0 \\
\hline TOPLAM & 1 & 5,0 & 19 & 95,0 & 3 & 15,0 & 17 & 85,0 \\
\hline
\end{tabular}

Tablo 2’ye göre basımı Millî Eğitim Bakanlığı Yayınları tarafından gerçekleştirilen kitapta 6 öykü; 20 karakter bulunmaktadır. Tabloya bakıldığında, öykülerde bulunan 20 karakterin 1'i $(\% 5,0)$ açık karakter özelliği göstermektedir. Aşağıda açık karakter kullanımına ilişkin doğrudan alıntılar verilmiştir: 
"Öykü, dedesinin kıyafetlerini görünce çok şaşırdı. - Aaa, sen asker mi oldun? - Gençken olmuştum. Öykü, asker kıyafetinin üzerindeki madalyayı göstererek, - Peki, bu nedir dedeciğim, diye sordu. - Bu, vatanımızı düşmanlardan kurtarmak için savaşa katılan askerlere verilir." (Dedemin Madalyası, s.105)

Dedemin Madalyası adlı öyküde dede karakterinin geçmişi ve duygularına ilişkin bilgilere yer verildiği için dede karakteri, açık karakter özellikleri sergilemektedir.

Bulgular incelendiğinde kitaptaki öykü karakterlerinin \%95,0'i kapalı karakter özellikleri göstermektedir. Aşağıda kapalı karakter kullanımına ilişkin doğrudan alıntılar verilmiştir:

"Zeynep, kocaman bir salıncak ipi getirmiş." (Bir Okul Gezisi, s.73)

"Bir gün dedeleri hastalanınca köye gittiler. Dedeleri onlara özlemle sarıldı." (Ekranza, s.121)

Bir Okul Gezisi ve Ekranza adlı öykülerde Zeynep ve dede karakterlerini tanıtıcı bilgilere yer verilmediği için bu kişiler kapalı karakter özelliklerini yansıtmaktadır.

Tablo 2'de görüldüğü gibi, öykülerde bulunan 3 karakter $(\% 15,0)$ devingen karakter özelliği göstermektedir. Aşağıda devingen karakter kullanımına ilişkin doğrudan alıntılar verilmiştir:

"Odama geri döndüm. Bir yerden başlamak lazımdı. Katlanacakları katladım. Oyuncaklar oyuncak sepetine, kirliler kirli sepetine, kalemler kalemliğe. Çok da zor değilmiş hani." (Odam Lokanta, s.16)

"Elektronik hiçbir aletin olmadığı bu yer sanki başka bir gezegendi. Hiçbir şey ekranda gördüklerine benzemiyordu." (Ekranza, s.121)

Odam Lokanta adlı öyküde çocuk önceleri odasını hep dağınık bırakırken annesinin ev işlerinde ne denli yorulduğunun farkına vararak odasını düzenli tutmaya karar veriyor. Ekranza adlı öyküde ise Emre ve Eren karakterleri doğayı ilk defa görerek yaşama bakışları değişiyor. Öykülerde bu şekilde değişimlere giren çocuk, Emre ve Eren karakterleri devingen karakter özelliği göstermektedir.

Bulgular incelendiğinde kitaptaki öykü karakterlerinin \%85,0’i durağan karakter özellikleri göstermektedir. Aşağıda durağan karakter kullanımına ilişkin doğrudan alıntılar verilmiştir:

"Tam terliklerimi giyiyordum, annem salona geçti. Ah belim, ah sırtım, diye söyleniyordu. Tüm gün çalışır. Tozları kovalamadan, yerleri parlatmadan, yemekleri pişirmeden asla yatmaz." (Odam Lokanta, s.16)

"Gezi alanına varınca dedem salıncağımızı kurdu. Biz kızlarla voleybol oynadık, ip atladık." (Bir Okul Gezisi, s.74)

Odam Lokanta ve Bir Okul Gezisi adlı öykülerde anne ve dede karakterlerinin öykü içerisinde bir değişime girmedikleri için durağan karakter özellikleri yansıttığı belirtilebilir. 
Türkçe Ders Kitaplarında Yer Alan Öykülerdeki Kişilerin Karakter Özellikleri Üzerine Bir İnceleme

Tablo 3. 2. Sınıf Türkçe ders kitabına ilişkin bulgular

\begin{tabular}{lcccccccc}
\hline & \multicolumn{2}{c}{ Açılk } & \multicolumn{2}{c}{ Kapalı } & \multicolumn{2}{c}{ Devingen } & \multicolumn{2}{c}{ Durağan } \\
\cline { 2 - 9 } Öykü Adları & $\mathrm{f}$ & $\%$ & $\mathrm{f}$ & $\%$ & $\mathrm{f}$ & $\%$ & $\mathrm{f}$ & $\%$ \\
\hline Aile Fotoğrafları & - & - & 10 & 34,48 & - & - & 10 & 34,48 \\
\hline Gülcan İle Teyzesi & 1 & 3,44 & 1 & 3,44 & - & - & 2 & 6,89 \\
\hline Anne Kedi ve Yavruları & - & - & 3 & 10,34 & - & - & 3 & 10,34 \\
\hline Bayram Armağanı & 1 & 3,44 & 2 & 6,89 & - & - & 3 & 10,34 \\
\hline $\begin{array}{l}\text { Gazi Dede Cumhuriyeti } \\
\text { Anlatıyor }\end{array}$ & 1 & 3,44 & 2 & 6,89 & - & - & 3 & 10,34 \\
\hline Hastane Günlerim & & & & & & & & \\
\hline Üç Elma, Dört Öğrenci & - & - & 5 & 17,24 & 3 & 10,34 & 2 & 6,89 \\
\hline TOPLAM & 3 & 10,34 & 26 & 89,65 & 4 & 13,79 & 25 & 86,20 \\
\hline
\end{tabular}

Tablo 3'e göre basımı Dikey Yayıncılık tarafından gerçekleştirilen kitapta 7 öykü; 29 karakter bulunmaktadır. Tabloya bakıldığında, öykülerde bulunan 29 karakterin 3'ü $(\% 10,34)$ açık karakter özelliği göstermektedir. Aşağıda açık karakter kullanımına ilişkin doğrudan alıntılar verilmiştir:

"Gülcan iyi kalpli ve canlıları çok seven bir çocuktu. Her sabah, teyzesine kır çiçekleri toplamak için evlerinin yakınındaki kırlara giderdi." (Gülcan Ile Teyzesi, s.48)

"Küçük bir kasabada yaşayan bir adam varmış. Bu adamın bir oğlundan başka kimsesi yokmuş. Gün gelmiş, adamın oğlu evlenip büyük şehre taşınmış. Adamcağızsa iyice yaşlanmış. Artık gözleri iyi görmüyor, kulakları iyi işitmiyormuş. Kulübesinde bir başına yaşayıp gidiyormuş. Ihtiyar adam, oğlunu çok özlüyormuş. Bayramın gelmesini iple çekiyormuş." (Bayram Armağanı, s.46)

Gülcan Ille Teyzesi adlı öyküde Gülcan karakterinin kişilik özellikleri ve çiçek toplama rutini ve Bayram Armağanı adlı öyküde yaşlı adam karakterinin fiziksel ve ruhsal özellikleri okuyucuya aktarıldığı için bu kişiler açık karakter özelliği göstermektedir.

Bulgular incelendiğinde kitaptaki öykü karakterlerinin \%89,65’i kapalı karakter özellikleri göstermektedir. Aşağıda kapalı karakter kullanımına ilişkin doğrudan alıntılar verilmiştir:

"Gün gelmiş, adamın oğlu evlenip büyük şehre taşınmış." (Bayram Armağanı, s.46)

"Doktor Çağrı Bey, Büşra'ya serum bağlamış, serumun bitmesini bekliyorlardı." (Hastane Günlerim, s. 74)

Bayram Armağanı ve Hastane Günlerim adlı öykülerde oğul ve Büşra karakterlerini tanıtıcı bilgilere yer verilmediği için bu kişiler kapalı karakter özellikleri sergilemektedir.

Tablo 3’te görüldüğü gibi, öykülerde bulunan 4 karakter $(\% 13,79)$ devingen karakter özelliği göstermektedir. Aşağıda devingen karakter kullanımına ilişkin doğrudan alıntılar verilmiştir:

"Öğretmenlerinin koridorlarda koşmamaları için yaptığı uyarılara aldırış etmediğini düşünüyor ve pişmanlık duyuyordu." (Hastane Günlerim, s.75) 
"Aslında zor gibi görünen her sorunun çözümü kolaydır. Yeter ki çözmek için çaba gösterelim." (Üç Elma, Dört Öğrenci, s.88)

Hastane Günlerim adlı öyküde Büşra karakteri önceleri uyarılara uymamış ve hasta olmuş, bu sebeple daha önce yaptıklarını yapmayacağını ve pişmanlığını aktarmıştır. Üç Elma, Dört Öğrenci adlı öyküde ise öğrenciler sorunların çaba ile aşılacağını öğrenmişlerdir. Öykülerde bu şekilde değişimler geçiren Büşra ve öğrenci karakterleri devingen karakter özelliği göstermektedir.

Bulgular incelendiğinde kitaptaki öykü karakterlerinin \%86,20’si durağan karakter özellikleri göstermektedir. Aşağıda durağan karakter kullanımına ilişkin doğrudan alıntılar verilmiştir:

"Anneanne hala kentin dışındaki yazlığında oturuyordu." (Anne Kedi ve Yavruları, s.26)

"Öğretmenimiz, sıramızın üzerine üç tane elma bıraktı. Öğretmenler odasına gitti." (Üç Elma, Dört Öğrenci, s.88)

Anne Kedi ve Yavruları ve Üç Elma, Dört Öğrenci adlı öykülerde anneanne ve öğretmen karakterleri öykü içerisinde bir değişime girmedikleri için bu kişiler durağan karakter özellikleri sergilemektedir.

Tablo 4. 3. Sınıf Türkçe ders kitabına ilişkin bulgular

\begin{tabular}{lcccccccc}
\hline & \multicolumn{2}{c}{ Açık } & \multicolumn{2}{c}{ Kapalı } & \multicolumn{2}{c}{ Devingen } & \multicolumn{2}{c}{ Durağan } \\
\cline { 2 - 10 } Öykü Adları & $\mathrm{f}$ & $\%$ & $\mathrm{f}$ & $\%$ & $\mathrm{f}$ & $\%$ & $\mathrm{f}$ & $\%$ \\
\hline Dedem Anlatıyor & 1 & 3,57 & 2 & 7,14 & 1 & 3,57 & 2 & 7,14 \\
\hline Uçtu Hamdi Uçtu & - & - & 3 & 10,71 & - & - & 3 & 10,71 \\
\hline Kardan Adam & - & - & 6 & 21,42 & - & - & 6 & 21,42 \\
\hline Nevruz & 1 & 3,57 & 7 & 25,0 & - & - & 8 & 28,57 \\
\hline Sihirli Pasta & - & - & 4 & 14,28 & 2 & 7,14 & 2 & 7,14 \\
\hline Seyfi Dede & 1 & 3,57 & 3 & 10,71 & 1 & 3,57 & 3 & 10,71 \\
\hline TOPLAM & 3 & 10,71 & 25 & 89,28 & 4 & 14,28 & 24 & 85,71 \\
\hline
\end{tabular}

Tablo 4'e göre basımı Milî Eğitim Bakanlığı Yayınları tarafından gerçekleştirilen kitapta 6 öykü; 28 karakter bulunmaktadır. Tabloya bakıldığında, öykülerde bulunan 28 karakterin 3'ü (\%10,71) açık karakter özelliği göstermektedir. Aşağıda açık karakter kullanımına ilişkin doğrudan alıntılar verilmiştir:

"Dedem yaşlı. Atatürk dönemini görmüş. Kurtuluş Savaşı'na katılmış. Savaştan kalan kılıcı, Istiklal Madalyası ve savaş alanlarında çekilmiş fotoğrafları var. Hepsini özenle duvara asmış. Yılda birkaç kez birlikte siliyoruz. Temizlik yaparken hiç konuşmuyor. Resimleri elinde tutuyor. Okşar gibi bakıyor. Gözleri doluyor. Sanki eski günleri yeniden yaşıyor. Temizlik ve yerleştirme işi bitince odadan el ele çıkıyoruz. Başımı ve saçlarımı okşuyor." (Dedem Anlatıyor, s.31)

"Seyfi Dede, seksen doksan yaşlarında bir ayakkabı tamircisi. Galiba mahallemizin en yaşlı insanı. On üç on dört yaşlarındayken savaşa katılmış, yaralanmış. "Istiklal Madalyası" almış. Bu madalya 
Türkçe Ders Kitaplarında Yer Alan Öykülerdeki Kişilerin Karakter Özellikleri Üzerine Bir İnceleme

dükkânın duvarında asılı duruyor. Seyfi Dede'nin yüzü tırmıklanmış toprağa benziyor. Çizik çizik, buruşuk bir yüz. Beyaz, gri, parlak sarı karışımı değişik renkli bir sakalı var. Elleri sürekli titriyor. Arada bir burnunun ucuna taktığı küçük camlı bir gözlüğü var. Özellikle dikiş dikerken onu kullanıyor. Tatı dilli, konuşmayı seven birisi. Her zaman anlatacak bir şeyler buluyor. Savaştan, askerlikten, çocukluğundan." (Seyfi Dede, s.117)

Dedem Anlatıyor adlı öyküde dede karakterinin fiziksel özellikleri, ruhsal durumu ve geçmişi ile ilgili bilgiler ve Seyfi Dede adlı öyküde Seyfi Dede karakterinin kişilik özellikleri, geçmişi ve görünümü okuyucuya aktarıldığı için bu kişiler açık karakter özellikleri göstermektedir.

Bulgular incelendiğinde kitaptaki öykü karakterlerinin \%89,28'i kapalı karakter özellikleri göstermektedir. Aşağıda kapalı karakter kullanımına ilişkin doğrudan alıntılar verilmiştir:

"Tarık gülerken, -Amcacığım, bir dahaki sefere babam gibi bir kardan adam yaparız, dedi." (Kardan Adam, s.57)

"-Dahası var, dedi. Yengeniz bu pastayı hazırlarken tüm bu malzemeleri uygun şekilde bir araya getirdi. Fırında pişirdi. Tabaklara koydu. Bütün bunları yapan elleri de hesaba katın" (Sihirli Pasta, s.114)

Kardan Adam ve Sihirli Pasta adlı öykülerde Tarık ve yenge karakterlerini tanıtıı hiçbir bilgiye yer verilmediği için kapalı karakter özelliği sergilemektedir.

Tablo 4’te görüldüğü gibi, öykülerde bulunan 4 karakter $(\% 14,28)$ devingen karakter özelliği göstermektedir. Aşağıda devingen karakter kullanımına ilişkin doğrudan alıntılar verilmiştir:

"Bu konuşma sonunda ilk Cumhurbaşkanımız Atatürk'ün yaptıklarını iyice anladım." (Dedem Anlatıyor, s.35)

"Hiç düşünmeden, tereddüt etmeden dikişleri kesiyor. Yeniden yapacak! Titreyen elleriyle herkesten daha iyi yaptığına inandığım dikişleri, kendisi için kesiyor. İ̧̧ine sinmezmiş. Ben verilen işin kolayına kaçıyorum. Seyfi Dede, o yaşta en zorunu deniyor. Bıkmadan, usanmadan. Titreyen elleriyle uzatırken ayakkabımı: - Al bakalım ayakkabını, diyor. - Pırıl pırıl olmuş. Eskisinden yeni gözüküyor. Eminim çok da sağlamdır. Ayakkabılarımı uzattığı elini kapıp öpüyorum. - Dur deli çocuk dur! Elim çok kirli, diyor. Gözlerime bakıyor. Söz söylemek gereksiz. Beni anlıyor, bunu hissediyorum. Yine de söylüyorum: - Dede, ben de senin gibi olacağım! Işsim ne olursa olsun. Çöpçü olursam sokağım, dünyanın en temiz sokağı olacak. Memur olursam her işimi zamanında ve herkesten iyi yapacağım. Ne iş yaparsam yapayım kimseyi kandırmayacağım. Gülümsüyor, sıcacık gülümsüyor. Ben de gülümseyerek dükkândan çıkıyorum." (Seyfi Dede, s.118) 
Dedem Anlatıyor adlı öyküde çocuk önceleri Atatürk hakkında yeterli bilgiye sahip değilken dedesi sayesinde bu konudaki bilgileri değişmiştir. Seyfi Dede adlı öyküde ise çocuk karakteri yeni değerler ve erdemler geliştirerek değişime girmekte. Öyküde böyle bir değişime giren çocuk karakterleri devingen karakter özelliği göstermektedir.

Bulgular incelendiğinde kitaptaki öykü karakterlerinin \%85,71'i durağan karakter özellikleri göstermektedir. Aşağıda durağan karakter kullanımına ilişkin doğrudan alıntılar verilmiştir:

"Gözlerimi açtım ki kan ter içinde kalmışım. Hasan: Eee, sonra? Hamdi: Ne sonrası. Uyandım. Meğer düş görmüşüm..." (Uçtu Hamdi Uçtu, s.50)

"Sonra bayramların vazgeçilmez neferleri olan davulcu Mahmut Amca ile zurnacı Ekrem Dayı geldiler." (Nevruz, s.93)

Uçtu Hamdi Uçtu adlı öyküde Hasan ve Hamdi karakterleri öykü içerisinde herhangi bir değişim geçirmemiştirler. Nevruz adlı öyküde Mahmut Amca ve Ekrem Dayı karakterleri sürekli olarak aynı durumlarını korumakta ve buna devam etmektedir. Öykülerde değişime girmeyen Hasan, Hamdi, Mahmut Amca, Ekrem Dayı karakterleri durağan karakter özellikleri sergilemektedir.

Tablo 5. 4. Sınıf Türkçe ders kitabına ilişkin bulgular

\begin{tabular}{lcccccccc}
\hline & \multicolumn{2}{c}{ Açık } & \multicolumn{2}{c}{ Kapalı } & \multicolumn{2}{c}{ Devingen } & \multicolumn{2}{c}{ Durağan } \\
\cline { 2 - 10 } Öykü Adları & $f$ & $\%$ & $f$ & $\%$ & $f$ & $\%$ & $f$ & $\%$ \\
\hline $\begin{array}{l}\text { Babaanne ve Ihlamur } \\
\text { Ağacı }\end{array}$ & 3 & 5,66 & 3 & 5,66 & 1 & 1,88 & 5 & 9,43 \\
\hline İp Bacaklı Uzaylı Çocuk & 2 & 3,77 & 1 & 1,88 & 1 & 1,88 & 2 & 3,77 \\
\hline Gökyüzündeki Dost & 1 & 1,88 & 1 & 1,88 & - & - & 2 & 3,77 \\
\hline Oyuncakların Öfkesi & 1 & 1,88 & 9 & 16,98 & 1 & 1,88 & 9 & 16,98 \\
\hline En Büyük Takım Bizim & - & - & 5 & 9,43 & - & - & 5 & 9,43 \\
Takım & & & & & & & & \\
\hline Heyecan Doruklarda & - & - & 3 & 5,66 & - & - & 3 & 5,66 \\
\hline Şekerci Güzeli & 1 & 1,88 & 3 & 5,66 & - & - & 4 & 7,54 \\
\hline İstanbul Dünyam & - & - & 5 & 9,43 & - & - & 5 & 9,43 \\
\hline Ayşegül & - & - & 2 & 3,77 & - & - & 2 & 3,77 \\
\hline Ölümsüzleşen Bahçe & 1 & 1,88 & 3 & 5,66 & 1 & 1,88 & 3 & 5,66 \\
\hline Cambaz Ali & 1 & 1,88 & 8 & 15,09 & - & - & 9 & 16,98 \\
\hline TOPLAM & 10 & 18,86 & 43 & 81,13 & 4 & 7,54 & 49 & 92,45 \\
\hline
\end{tabular}

Tablo 5'e göre basımı Doku Yayıncılık tarafından gerçekleştirilen kitapta 11 öykü; 53 karakter bulunmaktadır. Tabloya bakıldığında, öykülerde bulunan 53 karakterin 10’u $(\% 18,86)$ açık karakter özelliği göstermektedir. Aşağıda açık karakter kullanımına ilişkin doğrudan alıntılar verilmiştir:

"Bu tepede dillere destan bir bahçe vardı. Bu bahçe, Selim Dede adlı yaşlı bir adamındı. Selim dede, bu bahçedeki kulübede tek başına yaşayan yoksul bir adamdı. Bahçe genişti. Tepedeki en geniş bahçelerden biriydi. Bahçede her türlü yemiş ağacı vardı. Ama bu yemişleri hiç satmazdı Selim dede. Çevredeki çocuklar, kendi bahçeleri gibi gelip yerlerdi yemişleri." (Ölümsüzleşen Bahçe, s.94) 
Türkçe Ders Kitaplarında Yer Alan Öykülerdeki Kişilerin Karakter Özellikleri Üzerine Bir İnceleme

"Üsküdar'ın en seçkin şekercisi, Alptekin Şekercisi'ydi. Orada, her şey taze olurdu. Kasada dükkân sahibinin oğlu otururdu. Onu, çevresindeki insanlardan ayıran, belirgin özellikleri vardı. Bu özellikler ona seçkin bir kişilik kazandırmıştı. Bu seçkinliği dükkânın asıl adını unutturmuş; dükkânın adı, halk arasında Şekerci Güzeli olmuştu. Bir kişi övülecek mi "Şekerci Güzeli gibi" denirdi; Şekerci Güzeli gibi kibar, Şekerci Güzeli gibi temiz, Şekerci Güzeli gibi sevgi dolu." (Şekerci Güzeli, s.72)

Ölümsüzleşen Bahçe ve Şekerci Güzeli adlı öykülerde Selim Dede ve Şekerci Güzeli karakterlerinin kişilik özellikleri ve yaşayışı okuyucuya aktarıldığı için açık karakter özelliği göstermektedir.

Bulgular incelendiğinde kitaptaki öykü karakterlerinin \%81,13’ü kapalı karakter özellikleri göstermektedir. Aşağıda kapalı karakter kullanımına ilişkin doğrudan alıntılar verilmiştir:

"Ak külahlı amca, pırıl pırıl, kocaman kavanozun kapağını açar, kepçeyi içeri daldıırdı." (Şekerci Güzeli, s.74)

"O yaz babam bizi Istanbul'a götürdü." (İstanbul Dünyam, s.84)

Şekerci Güzeli ve istanbul Dünyam adlı öykülerde Ak külahlı amca ve Baba karakterleri hakkında hiçbir bilgiye yer verilmediği için kapalı karakter özelliği sergilemektedir.

Tablo 5'te görüldüğü gibi, öykülerde bulunan 4 karakter $(\% 7,54)$ devingen karakter özelliği göstermektedir. Aşağıda devingen karakter kullanımına ilişkin doğrudan alıntılar verilmiştir:

"Hiç huysuzluk yapmayacağım demiş çocuk. Bütün yemeklerimi yiyeceğim. Çünkü senin gibi ip bacaklı, ip kollu, güçsüz bir çocuk olmak istemiyorum." (İp Bacaklı Uzaylı Çocuk, s.43)

"-Anneciğım, dedi yavaş̧̧a. Bundan sonra oyuncaklarımı hiç kırmayacağım. Kitaplarımı yırtmayacağım. N'olur, yarın bana yardım edin de kırık oyuncaklarımı onaralım, olur mu?" (Oyuncakların Öfkesi, s.62)

ip Bacakıı Uzaylı Çocuk adlı öyküde çocuk karakteri önceleri yemeklerini yemez ve annesine karşı gelir, sonrasında gördükleri karşısında düzenli beslenmenin önemini anlamıştır. Oyuncakların Öfkesi adlı öyküde ise Memo karakteri oyuncaklarına önem göstermeye başlamıştır. Öykülerde böyle bir değişim geçiren, çocuk ve Memo karakterleri devingen karakter özellikleri göstermektedir.

Bulgular incelendiğinde kitaptaki öykü karakterlerinin \%92,45’i durağan karakter özellikleri göstermektedir. Aşağıda durağan karakter kullanımına ilişkin doğrudan alıntılar verilmiştir:

"Çocuk etrafına bakınmış. Gerçekten de görünürde bir tek hayvan bile yokmuş. Ne suda balıklar ne gökyüzünde kuşlar ne kümeslerde tavuklar, ördekler, civcivler, tavşanlar... Her yer yalnız şeker ve çikolataymış. "Ne tuhaf bir gezegen burası." demiş çocuk. "Peki sebze yemeden, meyve yemeden, et 
yemeden burada çocuklar nasıl büyüyebiliyor?" "Neden büyüyemesinler?" demiş uzaylı çocuk. "Bak bana, pek güzel büyüyorum işte!" Çocuk, uzaylı çocuğa bakmış. Kolları incecikmiş. Boynu incecikmiş." (ip Bacaklı Uzaylı Çocuk, s.43)

"Bu ponponlu adam bunların hiçbirini yapamaz. Yapsa bile biz asla takımımızdan dönmeyiz. Babam bile bizi döndüremedikten sonra." (En Büyük Takım Bizim Takım, s.55)

Ip Bacaklı Uzaylı Çocuk adlı öyküde değişime girmeyen ip Bacaklı Uzaylı Çocuk karakteri durağan karakter özelliği göstermektedir. En Büyük Takım Bizim Takım adlı öyküde ise değişime girmeyen Çiğdem ve Murat karakterleri durağan karakter özellikleri göstermektedir.

Tablo 6. 5. Sınıf Türkçe ders kitabına ilişkin bulgular

\begin{tabular}{lcccccccc}
\hline & \multicolumn{2}{c}{ Açık } & \multicolumn{2}{c}{ Kapalı } & \multicolumn{2}{c}{ Devingen } & \multicolumn{2}{c}{ Durağan } \\
\cline { 2 - 10 } Öykü Adları & $f$ & $\%$ & $f$ & $\%$ & $f$ & $\%$ & $f$ & $\%$ \\
\hline Oyuncak & 1 & 2,32 & 4 & 9,30 & - & - & 5 & 11,62 \\
\hline Güneşin Uyuduğu Yer & - & - & 9 & 20,93 & - & - & 9 & 20,93 \\
\hline Bilmeyen Var mı? & - & - & 9 & 20,93 & 1 & 2,32 & 8 & 18,60 \\
\hline Püf Noktası & - & - & 2 & 4,65 & 1 & 2,32 & 1 & 2,32 \\
\hline Forsa & 2 & 4,65 & 3 & 6,97 & 1 & 2,32 & 4 & 9,30 \\
\hline Çocuk Doğru Söyledi & 1 & 2,32 & 5 & 11,62 & 2 & 4,65 & 4 & 9,30 \\
\hline Hasta & - & - & 4 & 9,30 & - & - & 4 & 9,30 \\
\hline Kar Tanesinin Serüveni & 1 & 2,32 & 2 & 4,65 & - & - & 3 & 6,97 \\
\hline TOPLAM & 5 & 11,62 & 38 & 88,37 & 5 & 11,62 & 38 & 88,37 \\
\hline
\end{tabular}

Tablo 6'ya göre basımı Milli Eğitim Bakanlığı Yayınları tarafından gerçekleştirilen kitapta 8 öykü; 43 karakter bulunmaktadır. Tabloya bakıldığında, öykülerde bulunan 43 karakterin 5’i $(\% 11,62)$ açık karakter özelliği göstermektedir. Aşağıda açık karakter kullanımına ilişkin doğrudan alıntılar verilmiştir:

"Kendini gemiye getiren askerlerle birlikte yürüdü. Kara, pala bıyıklı, sırmalı elbisesinin üzerine çelik zırhlar giymiş bir adamın karşısında durdu. -Sen, Kara Memiş misin? -Evet, dedi. -Aç bakayım sağ kolunu. ihtiyar, kaftanın altından kolunu çıkardı, Bey'e uzattı. Pazısında haç şeklinde derin bir yara izi vardı. Bu yarayı, gecesi altı ay süren bir adada savaşırken almıştı. Bey, ellerine sarıldı, öpmeye başladı. -Ben senin oğlunum, dedi. -Turgut musun? -Evet."(Forsa, s.140)

"Ben Hazar Denizi'nde bir damla suydum. Bir damlacık... Benim gibi milyarlarca, milyarlarca damlacık vardı. Birbirimize yapışıyor, denizin suyunu oluşturuyorduk. Bazen bir akıntıya kapılıyor, denizin içinde yer değiştiriyordum. Bazen yüzeye çıkıyordum. O zaman rüzgâr bizi üflüyor, dalga olarak kıyılara savuruyordu. O zaman kıyılara çarpıp geri dönüyorduk. Sıcak bir yaz günüydü. Yine denizin yüzeyine çıkmıştım. Yavaştan esen rüzgâr, minik dalgalar oluşturuyordu. Ben bir dalgadan diğerine geçiyordum. Mutluydum. Neşe doluydum." (Kar Tanesinin Serüveni, s.234) 
Türkçe Ders Kitaplarında Yer Alan Öykülerdeki Kişilerin Karakter Özellikleri Üzerine Bir İnceleme

Forsa adlı öyküde Turgut karakterinin fiziksel özellikleri, kaptanlık görevi ile ilgili bilgiler okura sunulduğu için bu karakter açık karakter özellikleri sergilemektedir. Bir Kar Tanesinin Serüveni adlı öyküde ise Kar Tanesi karakterinin yaşamı ve ruhsal durumu okuyucuya aktarıldığı için bu karakter açık karakter özelliği göstermektedir.

Bulgular incelendiğinde kitaptaki öykü karakterlerinin \%88,37'si kapalı karakter özellikleri göstermektedir. Aşağıda kapalı karakter kullanımına ilişkin doğrudan alıntılar verilmiştir:

"Hatta o okurken kırtasiyeci Mehmet Amca çıkıp eşlik etmesin mi?" (Bilmeyen Var mı?, s.40)

"Vaktiyle testi ve çanak çömlek imal edilen kasabalardan birinde, uzun yıllar bu meslekte çalışan bir çırak, kalfa olup artık kendi başına bir dükkân açmayı arzu eder olmuş. Ne yazık ki her defasında ustası ona: - Sen, demiş, daha bu işin püf noktasını bilmiyorsun, biraz daha emek vermen gerekiyor." (Püf Noktası, s.88)

Bilmeyen Var mı? ve Püf Noktası adlı öykülerde Mehmet Amca ve çırak karakterlerini tanıtıcı bilgilere yer verilmediği için bu karakterler kapalı karakter özellikleri sergilemektedir.

Tablo 6'da görüldüğü gibi, öykülerde bulunan 5 karakter $(\% 11,62)$ devingen karakter özelliği göstermektedir. Aşağıda devingen karakter kullanımına ilişkin doğrudan alıntılar verilmiştir:

"Sonraki gün sınıfta çıkıp okudum istiklal Marşı'nı. Hem de tıpkı, Salim Amca, Mehmet Amca, annem, babam, dedem, babaannem ve ablam gibi." (Bilmeyen Var mı?, s.43)

"Eski çırak ayağıyla merdaneyi döndürüp çamura şekil vermeye başladığında usta önünde dönen çanağa arada sırada "püf" diye üfleyerek zamanla testiyi çatlatacak olan bazı küçük hava kabarcıklarını patlatıp giderir. Böylece çırak da bu sanatın püf denilen noktasını öğrenmiş olur." (Püf Noktası, s.88)

Bilmeyen Var mı? adlı öyküde çocuk karakteri önceleri İstiklal Marşı'nı ezberlemeyi bir zorluk olarak görmektedir fakat çevresindeki herkesin bildiğini görmüş ve bu konudaki fikirleri değişerek İstiklal Marşıı'ı ezberlemiştir. Püf Noktası adlı öyküde çırak karakteri ustasının yardımıyla işinin püf noktasını öğrenmiştir. Öykülerde böyle değişimlere giren çocuk ve çırak karakterleri devingen karakter özelliği göstermektedir.

Bulgular incelendiğinde kitaptaki öykü karakterlerinin \%88,37'si durağan karakter özellikleri göstermektedir. Aşağıda durağan karakter kullanımına ilişkin doğrudan alıntılar verilmiştir:

"Hep kızımla torunumun evden çıkmalarını gözlüyorum oyuncaklarla oynamak için." (Oyuncak, s.10)

"Biraz sonra bacanağı gelir. Tevfik Efendi yeniden başlar: "Innh... dedim ya! Olacak olduynan oluyor! Yer düz, güzel yaya kaldırım, bizim vezne arabası durdu, ben de indim. Innh, atlar ürkmedi, kimse 
bana dokunmadı, düşmedim, ayağımı yere kor komaz, vay efendim sen misin koyan..." Yatak yumuşak, oda ılık, yaşayış tatlı, herkes sevimli, yalnız ne kadar yazık ki çok sürmüyor!" (Hasta, s.217)

Oyuncak ve Hasta adlı öykülerde dede ve Tevfik Efendi karakterleri öykü içerisinde bir değişime girmedikleri için durağan karakter özellikleri göstermektedir.

Tablo 7. 6. Sınıf Türkçe ders kitabına ilişkin bulgular

\begin{tabular}{lcccccccc}
\hline & \multicolumn{2}{c}{ Açık } & \multicolumn{2}{c}{ Kapalı } & \multicolumn{2}{c}{ Devingen } & \multicolumn{2}{c}{ Durağan } \\
\cline { 2 - 10 } Öykü Adları & $\mathrm{f}$ & $\%$ & $\mathrm{f}$ & $\%$ & $\mathrm{f}$ & $\%$ & $\mathrm{f}$ & $\%$ \\
\hline Affet Babacığım & - & - & 4 & 11,11 & 1 & 2,77 & 3 & 8,33 \\
\hline Şehit Bacı & 2 & 5,55 & 4 & 11,11 & - & - & 6 & 16,66 \\
\hline Akdeniz'le Röportaj & 1 & 2,77 & 7 & 19,44 & - & - & 8 & 22,22 \\
\hline Sınıf Başkanı & 1 & 2,77 & 5 & 13,88 & 1 & 2,77 & 5 & 13,88 \\
\hline $\begin{array}{l}\text { Çılgın Dedemin Zaman } \\
\text { Makinesi }\end{array}$ & 1 & 2,77 & 3 & 8,33 & 1 & 2,77 & 3 & 8,33 \\
\hline Atari Merakı & 1 & 2,77 & 7 & 19,44 & 1 & 2,77 & 7 & 19,44 \\
\hline TOPLAM & 6 & 16,66 & 30 & 83,33 & 4 & 11,11 & 32 & 88,88 \\
\hline
\end{tabular}

Tablo 7’ye göre basımı Milli Eğitim Bakanlığı Yayınları tarafından gerçekleştirilen kitapta 6 öykü; 36 karakter bulunmaktadır. Tabloya bakıldığında, öykülerde bulunan 36 karakterin 6'sı $(\% 16,66)$ açık karakter özelliği göstermektedir. Aşağıda açık karakter kullanımına ilişkin doğrudan alıntılar verilmiştir:

"Kağnı kolunun en sonundaki alaca önlük kuşanmış, başına benli bir car örtmüşs olan kadın, sırtına sardığı yavrusuyla bu sefere çıkmıştı. Bu kadın Şerife'ydi." (Şehit Bacı, s.16)

"Mehmet okulunda oldukça tanınmış bir çocuktu. Arkadaşları ona "Demokrat Mehmet" derdi. Doğrusu bu isim çok hoşuna giderdi. Okuldaki diğer Mehmetlerden farklı olduğunu düşünürdü."(Sınıf Başkanı, s.48)

Şehit Bacı adlı öyküde Şerife karakteri fiziksel özellikleri ile okuyucuya aktarıldığı için bu karakter açık karakter özelliği göstermektedir. Sınıf Başkanı adlı öyküde ise Mehmet karakterinin kişisel ve diğer insanlardan farklı özelliklerine yer verildiği için bu karakter açık karakter özelliklerini yansıtmaktadır.

Bulgular incelendiğinde kitaptaki öykü karakterlerinin \%83,33’ü kapalı karakter özellikleri göstermektedir. Aşağıda kapalı karakter kullanımına ilişkin doğrudan alıntılar verilmiştir:

"Sıra arkadaşı saf saf sordu: - Acaba hangisi daha iyidir?" (Sınıf Başkanı, s.49)

"Otobüs perona yaklaştı. Illk binen bendim. Yanıma yaşlı bir amca oturdu. Heyecanımdan anlamış olmalıydı.- Oğlum sen yalnız mı gidiyorsun? diye sordu.- Evet, yalnız gidiyorum.- Ne işin var?-̧̧ey... amca, dayımlara gidiyorum. Yaşı amca söylediğim yalana pek inanmadı. Benim yaşımda çocukların 
Türkçe Ders Kitaplarında Yer Alan Öykülerdeki Kişilerin Karakter Özellikleri Üzerine Bir İnceleme

yalnız başına bir yere gitmesinin sakıncalı olduğunu söyledi. Birçok tehlikeli durumla karşılaşabileceğimi özellikle belirtti." (Atari Merakı, s.82)

Sınıf Başkanı ve Atari Merakı adlı öykülerde sıra arkadaşı ve yaşlı amca karakterlerini tanıtıcı bilgilere yer verilmediği için bu kişiler kapalı karakter özellikleri sergilemektedir.

Tablo 7’de görüldüğü gibi, öykülerde bulunan 4 karakter $(\% 11,11)$ devingen karakter özelliği göstermektedir. Aşağıda devingen karakter kullanımına ilişkin doğrudan alıntılar verilmiştir:

"Can: "Baba sen yaşlandığında ben de seni buraya mı getireceğim?" diye sorunca, dünyası başına yıkıldı. O soruyla birlikte deliler gibi geri çevirdi arabayı. Barakaya ulaştığında "Beni affet baba!" diyerek babasının boynuna sarıldı. Baba oğul sıkı sıkı sarılmış ve çocuklar gibi hıçkıra hıçkıra ağlıyorlardı. Oğlu, "Baba beni affet, sana bu şekilde davrandığım için affet." diye söyleniyordu." (Affet Babacı̆̆ım, s.3)

“(..)Beklediğim araba geldi. Bindim. Otogardan çıktık. Hava kararmıştı kendimi hiç iyi hissetmiyordum. Karnım acıkmıştı ama üzüntüm, tedirginliğim, açlığımı bastırmıştı. Uyumuşum ki hostesin dürtmesiyle uyandım. Otobüsten indim. Annem öyle sarıldı ki içten öptü öptü öptü... Babam daha soğukkanlıydı. Elini omzuma attı. O sıcaklığı hiçbir yerde bulamayacağımı biliyordum. Babam:Dündar, hiç böyle düşüncesizce davranılır mı? dedi. Annem hıçkırıklarla ağlıyordu. Onları böyle üzmeye hakkım yoktu. (...) Evimize gidince doğru odama gittim. Annemlere bir yazı yazmaya başladım. Sevgili Anneciğim ve Babacığım, Sizi çok üzdüğümün farkındayım. Ben yaptığım yanlış davranışla sizi çok üzdüm. Binlerce kez özür diliyorum. Bundan sonra atari oynamayı bıraktım. Sizleri üzdüğüm için çok utanıyorum. Beni bağışlarsanız çok mutlu olacağım. Sizden başka bir şey istemiyorum. Ne olur beni affedin. Oğlunuz Dündar." (Atari Merakı, s.83)

Affet Babacığım adlı öyküde baba(oğul) karakteri babasını ıssız bir eve terk edecekken oğlu Can’ın sorusu sonrasında yanlış yaptığını anlamış ve fikrini değiştirerek babasını terk etmemiştir. Atari Merakı adı öyküde Dündar karakteri yaptığı sorumsuz davranışları anlamış ve bunları değiştirmek istemektedir. Öykülerde değişimlere giren baba(oğul) ve Dündar karakterleri devingen karakter özelliği göstermektedir.

Bulgular incelendiğinde kitaptaki öykü karakterlerinin \%88,88'i durağan karakter özellikleri göstermektedir. Aşağıda durağan karakter kullanımına ilişkin doğrudan alıntılar verilmiştir:

"Eşi, babasını istemiyor ve onun evde bir fazlalık olduğunu düşünüyordu. (...) Yine böyle bir tartışma anında eşi bütün bağları kopardı ve: "Ya ben giderim, ya da baban bu evde kalmayacak." diyerek rest çekti." (Affet Babacığım, s.2) 
"Necdet daha önce ne yapıyorsa onu yapmayı tercih etti. Kendisine oy vermeyenleri döveceğini söyleyerek, seçmeni korkutarak başkanlığı kazanacağını umuyordu." (Sınıf Başkanı, s.50)

Affet Babacığım adlı öyküde kadın(eş) karakteri fikirlerini değiştirmek istememektedir. Sınıf Başkanı adlı öyküde ise Necdet karakteri sınıf başkanlığı seçimini kazanmak amacıyla her seferinde insanları tehdit etmektedir. Öykü içerisinde bir değişime girmeyen kadın(eş) ve Necdet karakterleri durağan karakter özellikleri göstermektedir.

Tablo 8. 7. Sınıf Türkçe ders kitabına ilişkin bulgular

\begin{tabular}{lcccccccc}
\hline & \multicolumn{2}{c}{ Açık } & \multicolumn{2}{c}{ Kapalı } & \multicolumn{2}{c}{ Devingen } & \multicolumn{2}{c}{ Durağan } \\
\cline { 2 - 10 } Öykü Adları & $f$ & $\%$ & $f$ & $\%$ & $F$ & $\%$ & $f$ & $\%$ \\
\hline Ben Bir Küçük Kilimim & 1 & 5,26 & 4 & 21,05 & 1 & 5,26 & 4 & 21,05 \\
\hline Atatürk'ü Anlamak & - & - & 3 & 15,78 & 1 & 5,26 & 2 & 10,52 \\
\hline Son Kuşlar & 3 & 15,78 & 6 & 31,57 & - & - & 9 & 47,36 \\
\hline Ayşe Gül & - & - & 2 & 10,52 & - & - & 2 & 10,52 \\
\hline TOPLAM & 4 & 21,05 & 15 & 78,94 & 2 & 10,52 & 17 & 89,47 \\
\hline
\end{tabular}

Tablo 8'e göre basımı Ez-De Yayıncılık tarafından gerçekleştirilen kitapta 4 öykü; 19 karakter bulunmaktadır. Tabloya bakıldığında, öykülerde bulunan 19 karakterin 4'ü $(\% 21,05)$ açık karakter özelliği göstermektedir. Aşağıda açık karakter kullanımına ilişkin doğrudan alıntılar verilmiştir:

"Benim örgümde tam on sekiz çeşit boya, on bir çeşit de nakış vardır. (...) Üç yıldan beri her gün bir parça sola sola ölüp gidiyorum. (...) Ben bir küçük kilimim. Alçak gönüllüyüm, kalenderim ve haddimi bilirim. Biricik ödevim insanlara bir tutam durulmuş renk, bir avuç drurulmuş biçim sunmaktır." (Ben Bir Küçük Kilimim, s.12)

"Kahvecinin kendisi sevimsiz bir adamdır. Kahveciden çok, ters bir devlet memuru hüviyeti taşır. Hastalıklı olmasa doktorlar fazla yorulmamasını salık vermemiş olsalar dünyada kahveci olmazdı." (Son Kuşlar, s.88)

Ben Bir Küçük Kilimim adlı öyküde kilim karakterinin fiziksel ve kişisel özellikleri okura sunulduğu için bu karakter açık karakter özelliklerini yansıtmaktadır. Son Kuşlar adlı öyküde ise kahveci karakteri kişilik özellikleri ile okuyucuya aktarıldığı için açık karakter özelliği göstermektedir.

Bulgular incelendiğinde kitaptaki öykü karakterlerinin \%78,94’ü kapalı karakter özellikleri göstermektedir. Aşağıda kapalı karakter kullanımına ilişkin doğrudan alıntılar verilmiştir:

"ihtiyar, yünlerin boyanması için dağ köylerinde nam salmış Duru Kadın'a göndermek istedi." (Ben Bir Küçük Kilimim, s.10)

"-Mühendis Ahmet Bey söktürüyor." (Son Kuşlar, s.91)

Ben Bir Küçük Kilimim ve Son Kuşlar adlı öykülerde Duru Kadın ve Mühendis Ahmet Bey karakterini tanıtıcı bilgilere yer verilmediği için bu kişiler kapalı karakter özellikleri sergilemektedir. 
Türkçe Ders Kitaplarında Yer Alan Öykülerdeki Kişilerin Karakter Özellikleri Üzerine Bir İnceleme

Tablo 8'de görüldüğü gibi, öykülerde bulunan 2 karakter $(\% 10,52)$ devingen karakter özelliği göstermektedir. Aşağıda devingen karakter kullanımına ilişkin doğrudan alıntılar verilmiştir:

"Ah gözünü sevdiğim küçük kilim! Ben senin ne kadar alçak gönüllü olduğunu nasıl bilmem; bilirim. Seni vaktiyle kök boyalarıla, solmaz renklerle dokurlar gene ayak altına serer, gene en zahmetli işlerde kullanırlardı. Sen bütün göçlerde bütün evin kabını kacağını sarıp sarmalarsın. Sen çadır olur çatı kurar, üst üste serilir kaba döşek kesilir, paçavra olur mutfakta iş görür, paspas olur kapılarda nöbet beklersin." (Ben Bir Küçük Kilimim, s.12)

"Daha sonra öğrendiklerimi derste sınıf arkadaşlarımla paylaştım. Arkadaşlarım beli alkışladı. Öğretmenim çalışmamı çok beğendi ve beni yanaklarımdan öptü. Ama benim için en büyük ödül öğrendiklerimdi." (Atatürk'ü Anlamak, s.29)

Ben Bir Küçük Kilimim adlı öyküde ortanca gelin karakteri kilimi hazır boyayla boyamış, daha sonra kendi geleneklerine dönmenin önemini anlamıştır. Öyküde böyle bir değişime giren ortanca gelin karakteri devingen karakter özelliği göstermektedir. Atatürk'ü Anlamak adlı öyküde çocuk karakteri Atatürk ve ülkemiz ile ilgili yeni değer ve erdemler geliştirdiği için bu karakter devingen karakter özelliklerini yansıtmaktadır.

Bulgular incelendiğinde kitaptaki öykü karakterlerinin \%89,47'si durağan karakter özellikleri göstermektedir. Aşağıda durağan karakter kullanımına ilişkin doğrudan alıntılar verilmiştir:

"Gelin; bunun uzun ve masraflı olduğunu, zaten Duru Kadın'ın da seksen seneden beri sekiz boya bellediğini, boyuna onları tekrarlayıp durduğunu söyledi." (Ben Bir Küçük Kilimim, s.10)

"Havalar sertleşir, poyrazlar, lodoslar birbirini kovalar, günün birinde teşnirlerin sonlarına doğru, ılık, hiç rüzgârsız parça parça oynamayan bulutlu, tatlı, sümbüli günlerde, o en çığırtkan kafes kuşunun nereden bulursa bulur, mahalle çocuklarını çağırtır; bin tanesi iki yüz elli gram et vermeyen sakalları, iskeletleri, Floryaları, aralarına karışmıs serçeleri gökyüzünden birer birer toplardı." (Son Kuşlar, s.90)

Ben Bir Küçük Kilimim ve Son Kuşlar adlı öykülerde Duru Kadın ve Konstantin Efendi karakterleri öykü içerisinde bir değişime girmediği için durağan karakter özellikleri göstermektedir.

Tablo 9. 8. Sınıf Türkçe ders kitabına ilişkin bulgular

\begin{tabular}{|c|c|c|c|c|c|c|c|c|}
\hline \multirow[b]{2}{*}{ Öykü Adları } & \multicolumn{2}{|c|}{ Açık } & \multicolumn{2}{|c|}{ Kapalı } & \multicolumn{2}{|c|}{ Devingen } & \multicolumn{2}{|c|}{ Durağan } \\
\hline & $f$ & $\%$ & $f$ & $\%$ & $f$ & $\%$ & $f$ & $\%$ \\
\hline $\begin{array}{l}\text { Okuma Serüvenim Nasıl } \\
\text { Başladı? }\end{array}$ & 1 & 3,12 & 9 & 28,12 & 2 & 6,25 & 8 & 25,0 \\
\hline $\begin{array}{l}\text { Karanfiller ve Domates } \\
\text { Suyu }\end{array}$ & 1 & 3,12 & 7 & 21,87 & 1 & 3,12 & 7 & 21,87 \\
\hline Martı & 1 & 3,12 & 6 & 18,75 & 1 & 3,12 & 6 & 18,75 \\
\hline İmece & - & - & 7 & 21,87 & - & - & 7 & 21,87 \\
\hline TOPLAM & 3 & 9,37 & 29 & 90,62 & 4 & 12,50 & 28 & 87,50 \\
\hline
\end{tabular}


Tablo 9'a göre, basımı Milli Eğitim Bakanlığı Yayınları tarafından gerçekleştirilen kitapta 4 öykü; 32 karakter bulunmaktadır. Tabloya bakıldığında, öykülerde bulunan 32 karakterin 3'ü $(\% 9,37)$ açık karakter özelliği göstermektedir. Aşağıda açık karakter kullanımına ilişkin doğrudan alıntılar verilmiştir:

"Köyde ona "Kör Mustafa" derlerdi. Bir gözü sola doğru biraz kaymıştı. Sağ tarafının beyazı ile göz kapağı arasına ciğer kırmızısı bir et parçası oturmuştu. Böyle mi doğmuştur? Yoksa çocukken bir şey mi batmıştır? Bu arızalı göz, öteki gözden daha parlaktır, daha siyah, daha canlı, daha zekidir. Bana bir kamburu hatırlatıyor bu göz; tuhaf değil mi? (...) Işste Kör Mustafa'nın bu gözü de bir kambur insanın ruh hâletini içine sindirmiş, şıkır şıkır, pırıl pırıl, sevimli, çapkın, canlı bir gözdür. Öteki doğru dürüst göz, onun yanında mahcup, sönük, tatsız tuzsuz, pek de kibirlidir. Kör Mustafa bahçelerde çalışır, gündeliğe gider, sarnıç sıvar, dam aktarır, kuyu kazar..." (Karanfiller ve Domates Suyu, s.57)

"Martı Jonathan (Canıtın), durgun bir denizde ve üzerinde güneşin altın gibi parladığı bir kıyıda yaşar. Martı Jonathan çoğu martının yapamadığı şeyleri yapmaktadır. Çok yükseklere uçmak ve ilginç hareketler yapmak gibi... Jonathan'ın bu özellikleri onu diğer martılardan uzaklaştırmaktadır." (Martı, s.60)

Karanfiller ve Domates Suyu öyküsünde Kör Mustafa karakterinin çeşitli fiziksel özellikleri ve hayatını nasıl kazandığı okuyucuya aktarıldığı için bu kişi açık karakter özellikleri göstermektedir. Martı adlı öyküde ise Martı Jonathan'ın yaşamı, hayalleri ve farklılıkları okuyucuya sunulduğu için bu karakter açık karakter özellikleri göstermektedir.

Bulgular incelendiğinde kitaptaki öykü karakterlerinin \%90,62'si kapalı karakter özellikleri göstermektedir. Aşağıda kapalı karakter kullanımına ilişkin doğrudan alıntılar verilmiştir:

"Gene aynı yıl akrabalarımızdan dayı dediğimiz bir yakınımız, bize bir hikâye kitabı armağan etti." (Okuma Serüvenim Nasıl Başladı?, s.12)

"Derken tarlaya geldik. Büyük bir tarlanın ekini biçilecekti. Şimdi aklımda kaldığına göre tarlanın sahibi altı aydır hastaydı. Bu imece, bir yardım imecesiydi. Tarlanın ekini biçilecek, sonra harman edilecekti." (Imece, s.79)

Okuma Serüvenim Nasıl Başladı? ve Imece adlı öykülerde dayı ve tarla sahibi karakterlerini tanıtıcı bilgilere yer verilmediği için bu kişiler kapalı karakter özellikleri sergilemektedir.

Tablo 9'da görüldüğü gibi, öykülerde bulunan 4 karakter $(\% 12,50)$ devingen karakter özelliği göstermektedir. Aşağıda devingen karakter kullanımına ilişkin doğrudan alıntılar verilmiştir:

"Okumanın bir şeye "anlam yükleme" olduğunu öğrenmemize de daha vakit var ancak ciddi okuma için yeterli birikimimizin oluşmuş olduğunu söyleyebilirim." (Okuma Serüvenim Nasıl Başladı?, s.15) 
Türkçe Ders Kitaplarında Yer Alan Öykülerdeki Kişilerin Karakter Özellikleri Üzerine Bir İnceleme

"Uğraştığı konu "hız" konusuydu ve bir haftalık denemeden sonra bu konuda, yeryüzünde yaşayan en hızlı martıdan daha çok şey öğrendi." (Martı, s.62)

Okuma Serüvenim Nasıl Başladı? adlı öyküde anlatıcı karakter okuma ile ilgili yeni anlamlar ortaya çıkarmıştır. Martı adlı öyküde ise Martı Jonathan karakteri çabalayarak en hızlı martıdan bile daha çok şey öğrenmiştir. Öykülerde değişime giren anlatıcı ve Martı Jonathan karakterleri devingen karakter özelliği göstermektedir.

Bulgular incelendiğinde kitaptaki öykü karakterlerinin \%87,50’si durağan karakter özellikleri göstermektedir. Aşağıda durağan karakter kullanımına iliş̧in doğrudan alıntılar verilmiştir:

"Kış pek uzak değil. Balıkçı tekneleri azalacak ve yüzey balıkları derinlere inecekler. Eğer çalışman gerekiyorsa, bir şey öğrenmen gerekiyorsa yiyeceğini nasıl bulacağını öğren. Bütün bu uçma işi iyi, güzel de biliyorsun, süzülmeyi yiyemezsin. Unutma ki uçmanın nedeni karın doyurmaktır." (Martı, s.62)

"Ayna tutmayı bir Hıdırellez günü gördüm. Bir delikanlı kalenin üstünden, ta aşağıdaki Ceyhan kıyısındaki düzlükte eğlenen kızların içindeki sevgilisine ayna tutuyordu. Sonra ayna tutmayı çok gördüm. Aynanın şavkı, benim kafamda aşkla birleşti. Ne zaman ayna şavkı görsem aklıma hep renkli Hıdırellez gelir, aşk gelir." (imece, s.78)

Martı adlı öyküde baba karakteri yenilik ve değişimlere kapalı durmaktadır. Imece adlı öyküde anlatıcı karakter herhangi bir değişime girmemiştir. Öykü içerisinde bir değişime girmeyen baba ve anlatııı karakterleri durağan karakter özelliklerini yansıtmaktadır.

Tablo 10. MEB Yayınları ile özel yayınevleri kitaplarının karşılaştırmasına ilişkin bulgular

\begin{tabular}{|c|c|c|c|c|c|c|c|c|c|}
\hline \multirow[b]{2}{*}{ Yayınevleri } & \multicolumn{2}{|c|}{ Açık } & \multicolumn{2}{|c|}{ Kapalı } & \multicolumn{2}{|c|}{ Devingen } & \multicolumn{2}{|c|}{ Durağan } & \multirow[t]{2}{*}{ Toplam } \\
\hline & $f$ & $\%$ & $f$ & $\%$ & $f$ & $\%$ & $f$ & $\%$ & \\
\hline MEB Yayınları & 18 & 11,32 & 141 & 88,67 & 20 & 12,57 & 139 & 87,42 & 159 \\
\hline Özel Yayınlar & 17 & 16,83 & 84 & 83,16 & 10 & 9,90 & 91 & 90,09 & 101 \\
\hline
\end{tabular}

Tablo 10'da MEB Yayınları kitaplarında toplam 159; basımı özel yayınevleri tarafından yapılan kitaplarda ise 101 karakter bulunduğu görülmektedir. Basımı MEB Yayınları tarafından yapılan kitaplarda bulunan öykülerdeki kişiler açıklık/kapalııı yönünden \%11,32'si açık; \%88,67'si kapalı, devingenlik/durağanlık açısından \%12,57'si devingen; \%87,42'si durağan karakter özellikleri taşımaktadır. Özel yayınevleri tarafından hazırlanan kitaplarda yer alan öykülerdeki kişiler ise açıklık/kapalılık yönünden \%16,33'ü açık; \%83,16'sı kapalı, devingenlik/durağanlık açısından \%9,90'ı devingen; \%90,09'u durağan karakter özellikleri göstermektedir. 


\section{Sonuç ve Öneriler}

Edebiyat metinlerinde kahraman/kahramanlar çocuk okur için birer özdeşim ve öykünme modelidir (Sever, 2007). İlkokul ve ortaokul Türkçe ders kitaplarında (1-8. sınıf) yer alan öykülerdeki karakterlerin özelliklerini incelemeyi amaçlayan bu çalışmada karakterlerin daha çok kapalı ve durağan karakter özelliği gösterdiği görülmektedir. Bununla birlikte, incelenen Türkçe ders kitaplarındaki öykülerde karakter özelliklerinin sınıf düzeyine göre dengeli bir dağılım göstermediği görülmektedir.

İlkokul ve ortaokul Türkçe ders kitaplarında (1-8. sınıf) yer alan öykülerde okur tarafından çeşitli yönleriyle tanımlanabilen açık karakterlerin sayısı oldukça sınırlıdır. İncelenen kitaplardaki öykülerde açık karakter özelliği gösteren kişilerin yüzdelik oranları sırasıyla; $1 . \operatorname{sınıf~\% 5,~} 2 . \operatorname{sınıf~\% 10,34,~}$ 3.sınıf $\% 10,71,4 . \operatorname{sınıf} \% 18,86,5 . \operatorname{sın}$ ıf $\% 11,62,6$. sınıf $\% 16,66,7 . \sin$ ıf $\% 21,05,8 . \sin$ ıf $\% 9,37$ olduğu belirlenmiştir. Çocuklar okudukları eserlerdeki kahramanlarla özdeşleşme ihtiyacı içerisindedir. Çocuk, kahramanla kendisi arasında bir bağlantı kurabilmesi için, kahramanın duygularını, yaşadıklarını, kişiliğini anlamaya intiyaç duyar (Çılgın, 2007). Bu olgudan hareketle açık karakterler, çocuğun kahramanları tanıyarak yeni arkadaşlıklar kurmasına olanak tanıyabilir. Buna karşılık incelenen 52 öykünün 24'ünde açık karaktere yer verilmediği görülmektedir. Bu durum olumsuz bir sonuç olarak değerlendirilebilir.

Araştırma konusu olan ilkokul ve ortaokul Türkçe ders kitapları incelendiğinde öykü içerisinde değişim göstererek yeni kişisel davranışlar elde eden, yeni değerler geliştiren devingen karakterlere az yer verildiği görülmektedir. İncelenen kitaplardaki öykülerde devingen karakter özelliği gösteren kişilerin yüzdelik oranları sırasıyla; $1 . \operatorname{sınıf~} \% 15,2 . \operatorname{sınıf} \% 13,79,3 . \operatorname{sınıf} \% 14,28,4 . \operatorname{sın} ı f$ \%7,54, 5.sınıf $\% 11,62,6 . \operatorname{sınıf~\% 11,11,~7.sınıf~\% 10,52,~8.sınıf~} \% 12,50$ olduğu görülmüştür. Devingen karakterler, öykünün başlangıcıyla sonu arasında değişim göstererek yeni kişisel davranışlar edinir, yeni değerler geliştirebilir. İlköğretim çağında okuma alışkanlığı edinmeye başlayan çocuklar, inandırıcılığı yüksek, devingen kahramanlardan etkilenir; onları öykünerek güzele, doğruya, iyiye yönelirler (Sever, 2007). Buna karşlık, incelenen 52 öykünün 28'inde devingen karaktere yer verilmediği görülmektedir. Bu, çocukların kahramanlara öykünme, okurluk donanımlarını geliştirme ve okuma uğraşını sürekli kılma yolunda atılması gereken adımları sekteye uğratacak bir durumdur.

Araştırmada incelenen kitaplar ayrıca, yayıncı türüne (MEB Yayınları ve özel yayınevleri) göre de karşılaştırılmıştır. Yapılan karşılaştırmaya göre özel yayınevleri tarafından basımı yapılan kitaplarda bulunan öykülerde açık karakter kullanım oranının daha çok olduğu buna karşılık, devingen karakter kullanım oranının ise MEB Yayınları tarafından hazırlanan kitaplarda daha fazla olduğu görülmektedir. Bu durum MEB Yayınları ders kitaplarındaki öykülerde açık karakter kullanımının daha az olduğunu, 
Türkçe Ders Kitaplarında Yer Alan Öykülerdeki Kişilerin Karakter Özellikleri Üzerine Bir İnceleme

özel yayınevlerinden çıkanlarda ise devingen karakter kullanımının daha az olduğunu ortaya koymaktadır.

Yapılan çalışmada Türkçe ders kitaplarında yer alan öykülerde toplam 260 kişi bulunduğu belirlenmiştir. Bu karakterlerin açıklık/kapalılık yönünden, \%13,46'sı açık; \%86,54'ü kapalı karakter özellikleri taşıdığı görülmektedir. Devingenlik ve durağanlık yönünden ise \%11,53'ü devingen; \%88,47'si durağan karakter özellikleri göstermektedir. Çocuk edebiyatında özellikle ilkokul ve ortaokul dönemindeki çocuklara yönelik kitaplarda, iyi geliştirilmiş (açık), devingen karakterler çocuk gerçekliğine daha uygundur (Sever, 2007). Buna karşın, incelenen öykülerde kapalı ve durağan karakter özellikleri taşıyan kişi sayısının daha fazla olduğu görülmektedir. Bu olgu çocukların insan ve toplum gerçeğini anlaması açısından olumsuz durumlar oluşturabilecek bir nitelik taşımaktadır.

Karagül ve İnce Samur (2017) da bu konudaki çalışmasında öykü karakterlerinin çoğunlukla "kapalı" ve "durağan" nitelikte olduğunu belirlemiştir. "Açık" ve "devingen" özelliğe sahip karakter sayısının ise az olduğu sonucuna varmışlardır.

Araştırmada ulaşılan sonuçlara göre şu öneriler sunulabilir:

- Illkokul ve ortaokul Türkçe ders kitapları için seçilen öyküler konusunda titizlik gösterilmesi, kitaplarda çocuğun özdeşim kurabileceği iyi geliştirilmiş ve devingen nitelikli karakterlerin olduğu öykülerin yer alması önerilmektedir.

- Bu çalışmada öykülerdeki kişilerin karakter özellikleri incelenmiştir. Ileride yapılacak araştırmalarda, ders kitaplarında yer alan diğer yazınsal türlere dönük metinlerin de bu kapsamda incelenmesi önerilmektedir.

\section{Kaynaklar}

Açıkgöz, B. (2008). İlköğretim 6. Sınıf Türkçe Ders Kitaplarının Kelime Serveti Bakımından Değerlendirilmesi. Afyon: Afyon Kocatepe Üniversitesi Sosyal Bilimler Enstitüsü, Yayımlanmamış Yüksek Lisans Tezi.

Akyol, H. (2001). Ilköğretim Okulları 5. Sınıf Türkçe Kitaplarındaki Okuma Metinleriyle ilgili Soruların Analizi. Kuram ve Uygulamada Eğitim Yönetimi Dergisi, 7(2), 169-178.

Aslan, C. (2006). Türkçe Ders Kitaplarında Türkçe Olmayan Sözcüklerin Kullanımı Üzerine Bir İnceleme. Ankara Üniversitesi Tömer Dil Dergisi, 133, 7-19.

Aslan, C. (2007). Yazınsal nitelikli çocuk kitaplarının çocuğun gelişim sürecindeki yeri. Bulunduğu eser: Sever, S.(Yay. Haz.) 2. Ulusal Çocuk ve Gençlik Edebiyatı Sempozyumu Bildiriler Kitabı (189-200). Ankara: Ankara Üniversitesi Basımevi.

Aydın, i. (2012). Illköğretim 8. Sınıf Türkçe Ders Kitabı'nın 'Duygular' temasında Yer Alan Okuma Metinlerine Metin dilbilimsel Bir Yaklaşım. Turkish Studies International Periodical For The Languages, Literature And History Of Turkish Or Turkic, 7(3), 381-407.

Aydın, i. S. ve Yangil, M. K. (2013). Türkçe Ders Kitaplarında Yer Alan Metinlerin Edimsel Sınıflandırılması. Turkish Studies International Periodical For The Languages, Literature And History Of Turkish Or Turkic, 8(1), 829-841. 
Ayverdi, İ. (2011). Misalli Büyük Türkçe Sözlük. İstanbul: Kubbealtı Neşriyat.

Bağcı, H. ve Ünal, Y. (2013). Illköğretim 8. Sınıf Türkçe Ders Kitaplarındaki Metinlerin Okunabilirlik Düzeyi. Ana Dili Eğitimi Dergisi, 1(3), 12-28.

Baş, B. (2003). Altıncı Sınıf Türkçe Ders Kitaplarında Metin Türleri Üzerine Bir İnceleme. Türklük Bilimi Araştırmaları, 13(13), 257-265.

Baş, B. ve Inan Yıldız, F. (2015). 2. Sınıf Türkçe Ders Kitabındaki Metinlerin Okunabilirlik Açısından İncelenmesi. Mersin Üniversitesi Ĕgitim Fakültesi Dergisi, 11(1), 52-61.

Bilgin, N. (2000). İçerik analizi. İzmir: Ege Üniversitesi Edebiyat Fakültesi Yayınları.

Bowen, G. A. (2009). Document analysis as a qualitative research method. Qualitative research journal, 9(2), 27-40.

Ceran, D. ve Bozarslan, Y. (2013). Illköğretim İkinci Kademe 7. Sınıf Türkçe Ders Kitaplarında Yer Alan Milli Kültür Temasındaki Metinlerin Nicelik ve Türkçe Programına Uygunluk Açısından Değerlendirilmesi. Ahi Evran Üniversitesi Kırşehir Eğitim Fakültesi Dergisi, 14(1), 271-286.

Creswell, J. W. (2013). Research design: Qualitative, quantitative, and mixed methods approaches. New York: Sage Publications.

Çakır, P. (2013). Türkçe Ders Kitaplarındaki Öykülerin Çocuğa Görelik ilkesi Açısından İncelenmesi. Turkish Studies International Periodical For The Languages, Literature And History Of Turkish Or Turkic, 8(1), 1171-1180.

Çalık, T. (2001). Türkçe Ders Kitaplarının Biçim ve Tasarımı. Konu Alanı Ders Kitabı Inceleme Kılavuzu. Editör: Leyla Küçükahmet. Ankara: Nobel Yayın Dağıtım.

Çılgın, A. S. (2007). Çocuk Edebiyatı. Morpa Kültür Yayınları: İstanbul.

Çoban, A. ve Tabak, G. (2011). İlköğretim 6. Sınıf Türkçe Ders Kitaplarındaki Hikâyelerin Hikâye Haritalama Yöntemine Göre İncelenmesi. Journal Of European Education, 1(1), 43-50.

Demir, S. ve Sinan, A. T. (2010). İlköğretim 6, 7 ve 8. Sınıflar Türkçe Ders Kitaplarındaki Öykülerin Metin Dil Bilimsel Yöntemler Işığında Değerlendirilmesi. Turkish Studies International Periodical For The Languages, Literature And History Of Turkish Or Turkic, 5(1), 886-929.

Dikey Yayıncılık (2017). Ilkokul Türkçe 2 Ders Kitabı Öğrenci Çalışma Kitabı (1, 2, 3. Kitaplar). Ankara: Dikey Yayıncılık.

Dilidüzgün, S. (2004). Okuma Öğretimi Hedefleri Bağlamında Türkçe Ders Kitaplarındaki Çocuk Edebiyatı Ürünleri. Hasan Ali Yücel Eğitim Fakültesi Dergisi, 1(2), 43-55.

Dilidüzgün, Ş. (2010). Türkçe Derslerinde Metin Etkinliklerinin Okuma-Anlama Kazanımlarını Gerçekleştirme Yeterliği-Bir Öykü Örneği. Hasan Âli Yücel Eğitim Fakültesi Dergisi, 7(1).

Doğan, B. ve Gülüşen, A. (2011). Türkçe Ders Kitaplarındaki (6-8) Metinlerin Değerler Bakımından Incelenmesi. Sosyal Bilimler Dergisi, 1(2), 75-102.

Doku Yayıncılık (2017). Illköğretim 4.Sınıf Türkçe Ders ve Öğrenci Çalışma Kitabı (1, 2, 3.Kitaplar). Ankara: Özgün Matbaacılık.

Ercan, A. N. (2014). 8. Sınıf Türkçe Ders Kitaplarındaki Şiirlerin Şekil, Tema ve Tür Açılarından İncelenmesi. Ana Dili Eğitimi Dergisi, 2(2), 15-27.

Erdoğan, T. (2007). İlköğretim 3. Sınıf Türkçe Dersi Öğretmen Kılavuz Kitabı ve Öğrenci Çalışma Kitabının Yapılandırmacı Yaklaşıma Uygunluğu. Mehmet Akif Ersoy Üniversitesi Eğitim Fakültesi Dergisi, 8(14), 163-172.

Esmer, E. (2011). İlköğretim Üçüncü Sınıf Türkçe Ders Kitabı Anlatı Metinlerinde Bakış Açısı Görünüşü-Hal Türü Etkileşimi ve Ön-Arka Plan Düzenlenişi. Dil ve Edebiyat Dergisi, 8(2), 19-37. 
Evren, Z. (2008). Illköğretim 6. Sınıf Türkçe Ders Kitaplarındaki Edebî Metinlerin Çocuk Edebiyatı Ölçütlerine Göre Değerlendirilmesi, Afyon: Kocatepe Üniversitesi Sosyal Bilimler Enstitüsü, Yayımlanmamış Yüksek Lisans Tezi.

Ez-De Yayıncılık (2017). Ilköğretim Türkçe 7 Ders Kitabı. Ankara: Ez-De Yayıncılık.

Fırat, H. ve Mocan, A. (2014). Türkçe Ders Kitaplarındaki Hikâyelerde Yer Alan Değerler. Türkiye Sosyal Araştırmalar Dergisi, 183(183), 25-49.

Göçer, A. (2008). Illköğretim Türkçe Ders Kitaplarının Ölçme ve Değerlendirme Açısından İncelenmesi. Atatürk Üniversitesi Sosyal Bilimler Enstitüsü Dergisi, 11(1), 197-210.

Güftâ, H. ve Kan, M. O. (2011). İlköğretim 7. Sınıf Türkçe Ders Kitabının Dil ile İlgili Kültür Ögeleri Açısından İncelenmesi. Mustafa Kemal Üniversitesi Sosyal Bilimler Enstitüsü Dergisi, 8(15), 239-256.

Gür, T., Coşkun, İ. ve Sağlam, F. (2013). İlkokul 2, 3 ve 4. Sınıf Türkçe Ders Kitaplari Bütüncesinin Kelime Hazinesini Geliştirme Eğitimi Açısından İncelenmesi. Turkish Studies-International Periodical For The Languages, Literature And History Of Turkish Or Turkic, 8(1), 1308-2140.

Huck, C. S. (Ed.)(1982). "I Give You the End ot a Golden String" in Children's Literature. Theory into Practice, 21(4), 315-321.

Işık Demir, A. (2009). Yeni Programa Göre Hazırlanmış Ilköğretim 6. Sınıf Türkçe Ders Kitapları ve Bu Kitaplardaki Metinlerin Çocuk Edebiyatı Ölçütlerine Uygunluğu. Sakarya: Sakarya Üniversitesi Sosyal Bilimler Enstitüsü, Yayımlanmamış Yüksek Lisans Tezi.

Karadağ, Ö. ve Kurudayıŏlu, M. (2010). 2005 Türkçe Programına Göre Hazırlanmış İlköğretim Birinci Kademe Türkçe Ders Kitaplarının Kelime Hazinesi. Türklük Bilimi Araştırmaları, 27(27), 423-436.

Karagöz, B. (2009). Yapılandırmacı Yaklaşıma Göre Illköğretim 6 Ve 7. Sınıf Türkçe Ders Kitaplarındaki Değerlerin incelenmesi (Muğla ili Örneği). Muğla: Muğla Üniversitesi Sosyal Bilimleri Enstitüsü, Yayımlanmamış Yüksek Lisans Tezi.

Karagül, S. ve İnce Samur, A. Ö. (2017). Ortaokul Türkçe Ders Kitaplarında Yer Alan Öykülerdeki Kişilerin Karakter Özelliklerinin İncelenmesi. Ana Dili Eğitimi Dergisi, 5(2), 336-352.

Karataş, E. (2014). Çocuk Edebiyatında "Karakter" Kavramı. Sosyal ve Beşeri Bilimler Araştırmaları Dergisi, (33), 60-79.

Karatay, H. (2011). Karakter Eğitiminde Edebi Eserlerin Kullanımı. Turkish Studies-International Periodical For The Languages, Literature And History Of Turkish Or Turkic, 6(1), 1398-1412.

Karatay, H. ve Pektaş, S. (2012). Türkçe Ders Kitaplarının İncelenmesine Yönelik Ölçek Geliştirme Çalışması. Adıyaman Üniversitesi Sosyal Bilimler Enstitüsü Dergisi, 2012(10), 183-204.

Kıymaz, M. S. ve Koç, R. (2013). 6, 7, 8. Sınıf Türkçe Ders Kitaplarında Yer Alan Tiyatro Metinleri Üzerine Bir İnceleme. Adıyaman Üniversitesi Sosyal Bilimler Enstitüsü Dergisi, 2013(11), 821-849.

Kurudayıoğlu, M., Baş, B. ve Aytan, N. (2013). 7. Sınıf Türkçe Ders Kitaplarındaki Hikâyelerin Karakter Eğitimi Açısından İncelenmesi. Ana Dili Eğitimi Dergisi, 1(4), 22-37.

Küçük, S. (2011). Kültürler Arası Öğrenme Üzerine Bir Kavram-Model Denemesi ve Türkçe Ders Kitapları. Türklük Bilimi Araştırmaları, 29(29), 227-260.

Küçükavşar, A. ve Hasırcı, S. (2013). Türkçe Ders Kitaplarındaki Şiirlerin Çocuğa Göreliği. Mustafa Kemal Üniversitesi Sosyal Bilimler Enstitüsü Dergisi, 10(24), 57-76.

Küçükbasmacı, G. ve Öztürk, B. (2011). İlköğretim 6., 7., 8. Sınıf Türkçe Ders Kitaplarında Yer Alan Masal Metinlerinin Kültür Aktarımındaki Rolü. Kastamonu Eğitim Dergisi, 19(2), 671-688

MEB (2017). Illkokul Türkçe 1 Ders Kitabı. Ankara: Başak Matbaacılık.

MEB (2017). Illköğretim Türkçe 3 Ders ve Çalışma Kitabı (1, 2, 3.Kitaplar). Ankara: Devlet Kitapları. 
MEB (2017). ilköğretim Türkçe 8 Ders Kitabı. Ankara: Devlet Kitapları.

MEB (2017). Ortaokul Türkçe 5 Ders Kitabı. İstanbul: Bilnet Matbaacılık.

MEB (2017). Ortaokul Türkçe 6 Ders Kitabı. Ankara: Devlet Kitapları.

Merriam, S. B. (2013). Nitel araştırma: Desen ve uygulama için bir rehber (3.Basım). Ankara: Nobel Akademik Yayıncılık.

Mert, E. L. (2012). İlköğretim 6., 7. ve 8. Sınıf Türkçe Ders Kitaplarında Yer Alan Öykülerin Çocuk Yazınının Temel İlkeleri Bağlamında İncelenmesi. Amasya Üniversitesi Eğitim Fakültesi Dergisi, 1(1), 73-93.

Mirzaoğlu, V. ve Akın, E. (2016). 5.Sınıf Türkçe Ders Kitabındaki Metinlerin Okunabilirliği Üzerine Bir İnceleme. Siirt Üniversitesi Sosyal Bilimler Enstitüsü Dergisi, (5), 146-155.

Nayır, F. ve Kepenekci, Y. K. (2011). İlköğretim Türkçe Ders Kitaplarında Çocukların Katılım Hakları. Illköğretim Online, 10(1), 160-168.

Nutku, Ö. (2001). Dram Sanatı: Tiyatroya Giriş. İstanbul: Kabalcı Yayıncılık.

Okur, A. ve Arı, G. (2013). 6, 7, 8. Sınıf Türkçe Ders Kitaplarındaki Metinlerin Okunabilirliği. Illköğretim Online, 12(1), 202-226.

Öz, G. (2012). Ilköğretim Sekizinci Sınıf Türkçe Ders Kitaplarının Söz Varlığı Bakımından Incelenmesi. Malatya: İnönü Üniversitesi Sosyal Bilimler Enstitüsü, Yayımlanmamış Yüksek Lisans Tezi.

Özalp, B. (2011). Ilköğretim 1. ve 2. Sınıf Türkçe Ders Kitaplarındaki Metinlerin Kelime Sayısının Kişisel Kelime Servetine Katkısının Değerlendirilmesi. Konya: Selçuk Üniversitesi Eğitim Bilimleri Enstitüsü, Yayımlanmamış Doktora Tezi.

Özdemir, E. (2007). Yazınsal Türler (6. Basım). Ankara: Bilgi Yayınevi.

Özkan, H. İ. (2015). Öykü Türünün Türkçe Eğitimindeki Önemi, İşlevi ve Ortaokul Türkçe Ders Kitaplarındaki Öykülerin Incelenmesi. Konya: Mevlana Üniversitesi Sosyal Bilimler Enstitüsü, Yayımlanmamış Yüksek Lisans Tezi.

Sever, S. (2007). Çocuk ve Edebiyat (3.Basım). Kök Yayıncılık: Ankara.

Solak, M. ve Yaylı, D. (2009). İlköğretim İkinci Kademe Türkçe Ders Kitaplarının Türler Açısından İncelenmesi. Journal Of International Social Research, 2(9), 444-453.

Susar Kırmızı, F. (2014). 4. Sınıf Türkçe ders kitabı metinlerinde yer alan değerler. Değerler Eğitimi Dergisi, 12(27), 217-259.

Şahbaz, N. K. ve Çekici, Y. E. (2012). İlköğretim Türkçe 6, 7 ve 8. Sınıf Ders Kitaplarındaki Okuma Parçalarında Çocuk İmgeleri. Turkish Studies-International Periodical For The Languages, Literature And History Of Turkish Or Turkic, 7(2), 979-995.

Şimşek, T. (2005). Çocuk Edebiyatı. Konya: Suna Yayınları.

Tavşancıl, E. ve Aslan, E. (2001). Sözel, yazılı ve diğer materyaller için içerik analizi ve uygulama örnekleri. İstanbul: Epsilon.

Tekin, M. (2001). Roman Sanatı (Romanın Unsurları). İstanbul: Ötüken Yayınları.

Temizkan, M. ve Atasoy, A. (2014). Türkçe Ders Kitaplarında Yer Alan Hikâye Türündeki Metinlerin Üst Yapı Açısından Değerlendirilmesi. Uluslararası Türkçe Edebiyat Kültür Eğitim (Teke) Dergisi, 3(3), 210-237.

Temizkan, M. (2014). Ortaokul Türkçe Ders Kitaplarının Türkçe Dersi Öğretim Programındaki Temel Beceriler Açısından İncelenmesi. Ana Dili Eğitimi Dergisi, 2(1), 49-72.

Tolğay, N. (2011). Ilköğretim 4. ve 5. Sınıf Türkçe Ders Kitaplarında Bulunan Metinlerdeki Kelimelerin Çeşitliliği Bakımından incelenmesi. Konya: Selçuk Üniversitesi Eğitim Bilimleri Enstitüsü, Yayımlanmamış Doktora Tezi. 
Tüm, G. (2016). 5. ve 6. Sınıf Illköğretim Türkçe Ders Kitaplarında Yer Alan Metin Önü Ve Sonu Sorularının Bloom Taksonomisi'ne Göre Değerlendirilmesi. Turkish Studies-International Periodical For The Languages, Literature And History Of Turkish Or Turkic, 11(14), 731-748.

Uludoğan, O. (2008). 6. ve 7. Sınıflarda Okutulan Türkçe Ders Kitaplarındaki Düzyazı Metinlerinin Değerlendirilmesi. İzmir: Dokuz Eylül Üniversitesi, Yayımlanmamış Doktora Tezi.

Uzuner Yurt, S. (2017). 1. Sınıf Türkçe Ders Kitaplarındaki Şiirlerde İmgesel Dil Kullanımı. Turkish StudiesInternational Periodical For The Languages, Literature And History Of Turkish Or Turkic, 12(6), 799-810.

Yaylı, D. ve Kitiş Çınar, E. (2014). Ortaokul Türkçe Ders Kitapları Görsellerinde Toplumsal Cinsiyet. Turkish Studies-International Periodical For The Languages, Literature And History Of Turkish Or Turkic, 9(5), 2075-2096.

Yıldırım, A. ve Şimşek, H. (2011). Sosyal bilimlerde nitel araştırma yöntemleri. Ankara: Seçkin Yayıncılık.

\section{Extended Abstract Introduction}

The characters in children's literature texts are important to child readers. Children tend to identify themselves with the heroes in those narratives. Therefore, heroes with positive character traits need to be introduced. But, that doesn't mean that characters need to be over idealized (Şimsek, 2005: 29).

Sever (2007) classifies characters as open/closed and dynamic/stable. Open or well-developed characters are considered good by readers. Closed characters are introduced superficially and readers do not know much about them. Such characters remain in the background and direct the attention of the readers to the hero. The main purpose of the use of closed characters is to allow the children to compare the characteristics of the open character and the characteristics of the closed character. Dynamic characters are characters that change through the story and create new personal behaviors and develop new values. In addition, the change in the story must be convincing to the child reader. The child should be able to perceive the events that cause the changes, and cause and effect relationship should be established between the events. Otherwise, the child may lose interest in the story. Stable characters do not experience significant personality changes in the story (Sever, 2007).

The child identifies himself with a model in the process of his personality development. These examples are initially their parents and later replaced heroes in books. In this respect, unreliable fictional heroes may lead the child to not becoming able to identify himself with them or to identify himself with them in some negative way. Since the characters in the stories in textbooks are models for children, this research is important and necessary.

Method

This research uses document analysis. The document analysis method was adopted due to the fact that the books that were examined were the main sources of data. Document analysis allows the analysis of written materials that contain information in both printed and web-based documents in a systematic manner (Bowen, 2009; Yildirim and Simsek, 2011). .

A total of 52 stories were examined in the Turkish textbooks. 260 characters that were in the stories were evaluated, using the criteria of character traits developed by Sever (2007).

Results and Discussion

In this study, which aims to examine the traits of the characters in the stories in elementary and secondary school Turkish textbooks, the analysis showed that the characters were mostly closed and stable. However, it was observed that in the stories in the textbooks, character traits do not display a balanced distribution in terms of grade level.

Among the 52 stories that were examined, there were no open characters in 24 stories and no dynamic characters in 28 stories. This may be considered as a negative result.

Based on the results of the research, the following recommendations are presented:

- Care should be exercised in selecting stories for elementary and secondary school Turkish textbooks, and the textbooks should have stories that include well-developed and dynamic characters that children may identify themselves with.

- Other types of children's literature texts may also be scrutinized, using the criteria used in this study. 